\title{
The De causis in Thomas of York*
}

\author{
Fiorella Retucci \\ Philosophische Fakultät, Universität zu Köln and Università del Salento
}

The studies of the last years on the medieval reception of the Liber de causis have clearly revealed that, while the Liber de causis is a very important source of metaphysical doctrines within the Domenican order, ${ }^{1}$ the work had been read with suspicion and disinterest by the Franciscans.

In a recent article, Dragos Calma ${ }^{2}$ has ascertained this fact: Peckham quotes De causis explicitly only seven times; Ockham uses the text in merely six occasions (and in three of which he does not even openly indicate his source ${ }^{3}$ ); Scotus refers to six propositions of the Liber in nineteen explicit quotations. ${ }^{4}$ According to him, moreover, the Liber is just a vulgarization of Avicenna, and not a very good one at that. ${ }^{5}$

The situation does not change if we turn to the first Franciscan Masters, such as Alexander of Hales and Bonaventure. According to the scholarly

* I would like to express my deep gratitude to Dragos Calma for encouraging this work. I am also grateful to Andreas Speer, Loris Sturlese, Evan King and Lee Klein for carefully revising this study and to the team of great scholars, who are working on the critical edition of the Sapientiale within a joint program between the University of Salento and the Thomas-Institut Cologne (Sabina Tuzzo, Marco Maniglio, Antonio Punzi, Coralba Colomba, Diana Di Segni, Maxime Mauriège, Antonella Sannino).

1 For Albert the Great, for example, the Liber de causis represents the perfect completion of the Aristotelian Metaphysics: see Albert the Great, De causis et processu universitatis a prima causa, II, 1, p. 59, l. 19-6o, 1. 5: Pervenit autem ad nos et Physica per eundem modum ab eodem Philosopho perfecta, ubi istum librum 'Metaphysicam' nominavit, tituli eiusdem quattuor subiungens rationes. [...] Propter quod et iste liber (scil. Liber de causis) Philosophiae Primae coniungendus est, ut finalem ex isto recipiat perfectionem. On De causis as completion of the Aristotelian Metaphysics see Libera 1997.

2 Calma 2012, p. 234-236. Calma 2012, p. 236 defines the Franciscans' attitude toward the Liber de causis as disinterest and hostility: "Le désintérêt et même l' hostilité de certains franciscains à l' égard du Liber de causis restent plutôt énigmatiques."

3 For the implicit quotations in Ockham, see Bos 1992.

4 Bos 1992, p. 180, adn. 50 also validates this number. See also the contribution by J.-M. Counet in this volume.

5 John Duns Scotus, Ordinatio, II, dist. 2, pars 1, q. 4, p. 238,1-2: Ad primum argumentum principale dico quod doctrina De causis tradita est secundum doctrinam Avicennae erroneam [...]. 
literature, these Masters use the Liber "abundantly," ${ }^{6}$ but this turns out not to be the case. Indeed, a straightforward analysis of the explicit quotations shows how limited the influence of the Liber de causis was on both authors. Alexander refers to ten propositions of the Liber $^{7}$ for a total of eight quotations in his Commentary on the Sentences and a total of twenty-one in the so-called Summa Halensis. ${ }^{8}$ Bonaventure considers just thirteen propositions of the De causis. ${ }^{9}$ He quotes this text explicitly twenty-one times ${ }^{10}$ and does

6 Saffrey $2002^{2}$, p. XVIII: “Toujours est-il que, dans la décade 1220-12300, notre livre est abondamment utilisé et par Alxandre de Halès, qui comment alors pour la première fois les Sentences de Pierre Lombard à Paris, et par le premier maître dominicain, Roland de Crémone." D'Ancona, Taylor 2003, p. 642: "Alexandre de Halès utilise abondamment le $D e$ causis dans sa Summa Theologica [...] Les citations du De causis das les œuvres de saint Bonaventure sont nombreuses." Bardenhewer 1882, p. 236: "Das Buch de causis gelangt dabei [i.e. in Bonaventure's Sentences Commentary] zu sehr reicher und mannigfaltiger Verwendung."

$7 \quad$ Prop. 1, 2, 3, 5(6), 11(12), 13(14), 16(17), 17(18), 23(24), 30(31).

8 The quotations in Alexander of Hales are distributed as follows (the page number refers to the critical edition of Alexander's Opera Omnia, published by the Quaracchi). 1. Sent. I: Prop. 2 quoted at p. 117 and p. 118; Prop. 3 at p. 56; Prop. 5(6) at p. 38; Prop. 11(12) at p. 19 and p. 36o; Prop. 30(31) at p. 385. 2. Sent. II: one implicit quotation from Prop. 1 at p. 361. 3. Summa I: explicit references to De causis: Prop. 2 at p. 86b; Prop. 5(6) at p. 492a; Prop. $23(24)$ at p. $61 \mathrm{~b}$ and p. $76 \mathrm{a}$; Prop. $30(31)$ at p. 104b and p. 107a-b; explicit references to "Philosophus": Prop. 1 at p. 183 a and p. 484a. 4. Summa II, prima pars: explicit references to De causis: Prop. 30(31) at p. 132a; explicit references to "Philosophus": Prop. 1 at p. 503b; Prop. 2: at p. 73ob; Prop. 16(17) at p. 23ob; explicit references to the secondary propositions of De causis: Prop. 13(14) at p. 502b and p. 547a; references to De causis, but called by Alexander Liber de intelligentiis: Prop. 17(18) at p. 646a, 646b, 647a, 657a and p. 659b. 5 . Summa II, secunda pars: Prop. 1 at p. 17a. Summa III: Prop. 23(24) at p. 986b. See Prolegomena, in Alexandri de Hales Summa theologica, p. XCVI.

$9 \quad$ Prop. 1, 3, 4, 5(6), 9(10), 14(15), 15(16), 16(17), 17(18), 19(20), 23(24), 29(30), 30(31).

10 As explicit quotations (E.Q.) I consider: (1) quotations where Bonaventure explicitly mentions the title of De causis (fourteen quotations); (2) quotations where he refers explicitly to Aristotle or philosophus without mentioning the title of the Liber (seven quotations). In twenty one other occasions he quotes De causis without openly mentioning his source (I.Q.). There are also eight passages where Bonaventure says: quod recipitur in aliquo est per modum recipientis, non per modum recepti without mentioning a specific source. Although the editors refer frequently to De causis, I did not take these passages into consideration.List of explicit (E.Q.) or implicit letteral quotations (I.Q.) in Bonaventure's Opera omnia: 1. Sent. I: Prop. 1 at p. 221 (I.Q.); Prop. 1 at p. $370 b$ (I.Q.); Prop. 1 at p. 471 (E.Q.: Philosophus); Prop. 1 at p. 638 a (I.Q.); Prop. 4 at p. 167 b (E.Q.: auctor De causis); Prop. 5(6) at p. $39 \circ$ (E.Q.: Philosophus in libro De causis); Prop. 15(16) at p. 766a (E.Q.: Philosophus in libro De causis); Prop. 16(17) at p. 165b (I.Q.); Prop. 16(17) at p. 765a (E.Q.: Philosophus in libro De causis); Prop. 17(18) at p. 624b (I.Q.); Prop. 19(20) at p. 819b (E.Q.: Philosophus); Prop. 23(24), at p. 526a (E.Q.: Philosophus); Prop. 23(24) at p. 646a (E.Q.: Philosophus). 2. Sent. II: Prop. 3 at p. 452b (E.Q.: auctor in libro De causis); Prop. 4 at p. 33b (E.Q.: Philosophus De causis); Prop. 
not hesitate to openly criticize and condemn certain doctrines contained in the Liber. ${ }^{11}$

The name of Thomas of York, an important Franciscan of the middle of the 13th century, rarely appears in the historical reconstructions of the reception of the pseudo-Aristotelian book. Despite being "die einzige große Darstellung des Systems der Metaphyisik aus der Ära der Hochscholastik," as Martin Grabmann maintained, ${ }^{12}$ the Sapientiale is mentioned only occasionally in the introduction to the critical edition of Roger Bacon's Quaestiones super librum De causis (1935). There, the editor, Robert Steele, called attention to Thomas of York as an important author who has used De causis in the 13th century. ${ }^{13}$ Steele is indeed correct. In the Sapientiale, Thomas of York shows a deep confidence in his use of De causis and quotes it several times. This is exactly what this essay wants to show.

Written between 1250 and 1259/126o, while Thomas was at Oxford and Cambridge, the Sapientiale constitutes a complete metaphysics of being, beginning with an investigation of the existence, nature and properties of God, proceed-

9(10) at p. 118a (E.Q.: De causis); Prop. 15(16) at p. 865b (E.Q.: Philosophus in libro De causis); Prop. 16(17) at p. 39b (I.Q.); Prop. 16(17) at p. 559a (I.Q.); Prop. 29(30) at p. 66a (E.Q.: in libro De causis); Prop. 30 (31) at p. 55a (E.Q.: Philosophus in libro de causis); Prop. $30(31)$ at p. 65 a (E.Q.: Philosophus in libro De causis). 3. Sent. III: Prop. 16(17) at p. 691a (I.Q.); Prop. 23(24) at p. $701 \mathrm{a}$ (E.Q.: Philosophus); Prop. 23(24) at p. 702 b (I.Q.). 4. Sent. IV: Prop. 1 at p. 305 a (I.Q.); prop. 16(17) at p. 618b (I.Q.). 5. De scientia Christi: Prop. 16(17) at p. 35a (I.Q.); Prop. 15(16) at p. 42a (E.Q.: in libro De causis). 6. De myst. Trin.: Prop. 16(17) at p. 69a (E.Q.: De causis); Prop. 16(17) at p. 81b (E.Q.: De causis). 7. De perfect. evang.: Prop. 16(17) at p. 195a (E.Q.: Philosophus). 8. Itiner. mentis: Prop. 16 (17) at p. $310 a$ (I.Q.). 9. Coll. in Hex.: Prop. 3 at p. 442 b (E.Q.: Philosophus); Prop. 4 at p. 379b (I.Q.); Prop. 16(17) at p. 343b (I.Q.); Prop. 16(17) at p. 386a (I.Q.). 10. De Donis Spiritus Sancti: Prop. 3 at p. 496a (I.Q.); Prop. 14(15) at p. 498 b (I.Q.). 11. Comm. in Ioann.: Prop. 17(18) at p. 25 Oa (I.Q.). 12. Sermones de tempore: Prop. 16(17) at p. 352a (I.Q.); Prop. 17(18) at p. 271b (I.Q.).

11 See Bonaventura, Sententiae, II, dist. 18, art. 2, q. 3, p. 452b-453a: Quidam namque dixerunt, quod animarum productio est mediante Intelligentia, ut, sicut corpus caeleste ad productionem facit corporis humani, sic etiam Intelligentia ad productionem animae; et hoc plures senserunt philosophi, et sensisse videtur auctor in libro de Causis. [...] Sed haec tanquam haeretica abiicienda sunt et ostensa sunt esse falsa, supra distinctione prima. Unde verbum de Causis tanquam haereticum est respuendum, nisi quis intelligat, quod anima dicitur creari ab Intelligentia in hoc, quod aliquam illuminationem suscipit mediante illa. On this point, see D'Ancona Costa 1995, p. 73, n. 1. See also Bonaventura, In Hexaëmeron collatio, XI, 18, p. 379b: Unde dixit ille: "Prima rerum creatarum omnium est esse;" sed ego dico: prima rerum intellectualium est esse primum.

12 Grabmann 1913, p. 191.

13 Steele 1935, p. XX. 
ing to a doctrine of creation, followed by an inquiry into the division of being in general, and ending with a special metaphysics of physical being which remains unfinished.

The method and purpose of the work are openly declared by the author in the first four introductive chapters: first and foremost, the Sapientiale is a work written by a theologian for the purpose of coherently systematizing the doctrines of the philosophers in the clear attempt to realize a synthesis of Christian and philosophical wisdom.

Has autem utilitates et causas advertens ego minorum minimus elegi opus sudore plenum, et propter intellectus nostri imbecillitatem et ipsius operis difficultatem, de libris philosophicis congregare aliqua, que dixerunt de creatore et creaturis, quod estimo difficile propter eam, que paucis facta est, philosophie communicationem, verorum cum falsis confusionem, scientie sub verbis absconsionem. ${ }^{14}$

Thomas constructs his "incomparable monument du savoir philosophique"15 by collecting a massive number of theological and philosophical sources. Among them, De causis surely plays an important role, as the following numerical data demonstrate.

Thomas refers literally or explicitly to the Liber de causis one hundred four times within his Sapientiale. Moreover, there are three explicit quotations from the Liber in the so-called Comparatio sensibilium, a work which has to be considered not as an independent work, but as a first, primitive draft of the Sapientiale itself, as the research team engaged in the critical edition of the Sapientiale at the University of Salento has recently proven (see Appendix 2). ${ }^{16}$

Thomas knew, approved and used twenty-two propositions coming from the Liber in his own work, as the dossier attached to this study shows (see Appendix 1).

14 Thomas of York, Sapientiale, I, 3 (Ms Firenze, Biblioteca nazionale Centrale, Conv. Soppr. A.VI.437 [= F], f. $4^{\text {rb; }}$ Ms Città del Vaticano, Biblioteca Apostolica Vaticana, Vat. Lat. 6771 $[=\mathrm{R}]$, f. $16^{\mathrm{va}}$; MS Città del Vaticano, Biblioteca Apostolica Vaticana, Vat. Lat. $4301[=\mathrm{V}]$, f. $\left.4^{\mathrm{rb}}-4^{\mathrm{va}}\right)$.

15 Longpré 1926, p. 911.

16 On this point, see Punzi 2016. 
These figures alone might be sufficient to prove the interest of Thomas of York in the pseudo-Aristotelian work. They become more interesting, however, especially if we take a look at the influence of De causis on other authorsand this time outside the narrow frame of the Franciscan order. Berthold of Moobsurg, for example, explicitly refers to the authority of the anonymous work thirty-nine times, by quoting just sixteen propositions. ${ }^{17}$ Meister Eckhart, whose use of the Liber was more intensive, as scholars have shown, ${ }^{18}$ alludes to just eighteen chapters ${ }^{19}$ of the Liber in eighty explicit quotations. ${ }^{20}$

Like other medieval authors, Thomas of York was convinced that De causis was a composite work that comprised a certain number of propositions and a commentary to each of these. Thus, the propositions and the commentary are to be considered as two independent works of two independent authors. ${ }^{21}$

Thomas of York, however, did not go as far as his contemporary, Albert the Great ${ }^{22}$, in speculating about the composite authorship of the Liber de causis.

It is commonly believed that Thomas of York was persuaded of the Christian origins of the Liber de causis. The starting point of this opinion, shared by eminent scholars, such as Daniel Callus ${ }^{23}$ and Henri-Dominique Saffrey, ${ }^{24}$ derived from an erroneous indication of Ephrem Longpré in his well-known article on Thomas of York written in $1926 .{ }^{25}$

17 Prop. 1 [×4]; Prop. 1 comm. [×1]; Prop. 3 [×2]; Prop. 3 comm. [×8]; Prop. 4 [×2]; Prop. $5(6)$ [×1]; Prop. 9(10) [×1]; Prop. 11(12) [×1]; Prop. 13(14) [×1]; Prop. 14(15) [×2]; Prop. 14(15) comm. [×1]; Prop. 16(17) [×1]; Prop. 17(18) comm. [×5]; Prop. 18(19) comm. [×1]; Prop. 19(20) [×1]; Prop. 19(20) [×1]; Prop. 20(21) [×1]; Prop. 28(29) [×1]; Prop. 29(30) comm. [×1]; Prop. 30(31) [×2]; Prop. 3o(31) comm. [×1].

18 See Ruh 1996; Beierwaltes 2007; Retucci 2008; Meliadò 2013.

19 Prop. 1, 2, 3, 4, 5(6), 8(9), 9(10), 11(12), 12(13), 14(15), 15(16), 16(17), 17(18), 19(20), 20(21), 21(22), 23(24), 31(32).

20 A dossier with all quotations from De causis in Eckhart's works can be found in Retucci 2008, p. 157-164.

21 On this point, see D'Ancona 1992, p. 634-635; Saffrey $2002^{2}$, p. XXII.

22 See Albert the Great, De causis et processu universitatis, II, 1, 1, p. 61, 1. 65-68; De caelo et mundo, I, 3, 8, p. 73, l. 31 .

23 Callus 1943, p. 261: "[...] and even the author of the Liber de causis, who in the opinion of Thomas of York was a Christian."

24 Saffrey $2^{2002}{ }^{2}$, p. XIX: "Thomas d'York dans son Sapientiale range assez curieusement l'auteur parmi les sapientes christiani."

25 Longpré 1926. 
In the first book of the Sapientiale, Longpré found a quotation from a work on the first cause (De causa prima) written by an anonymous, but certainly Christian author:

Quare sequitur, quod Deus est, sicut exemplificat quidam de Christianis sapientibus in libro, quem fecit De causa prima, quod "non existente fonte essendi, nec erit fluens esse. Si enim totum esset fluens, non haberet, unde flueret. Nec enim a se ipso flueret nec per modum circuli, nec per modum infiniti." 26

Longpré came to the conclusion that the Liber de causa prima was, without question, the work better known under the title Liber de causis. ${ }^{27}$

Despite the fact that the abovementioned passage might resemble the wording of De causis, Longpré's assumption must be definitively be rejected. This is because the passage from the Liber de causa prima is actually a literal quotation from the De Trinitate by William of Auvergne, ${ }^{28}$ who was certainly, and not only in Thomas of York's opinion, a prominent authority of the Christian faith and Bishop of Paris.

Contrary to what Longpré, Callus and Saffrey believed, Thomas undoubtedly ascribed the Book of Causes to one among the sapientes mundi. An indication of this can be found in the fifteenth chapter of the first book of the Sapientiale. Here, Thomas recounts that there is no conflict concerning God's ineffability between the philosophers and the theologians: the former are represented by the Liber de causis, the latter by Saint Paul and pseudo-Dionysius the Areopagite.

26 Thomas of York, Sapientiale, I, 9 (F f. $9^{\mathrm{va}}$; R f. $23^{\mathrm{rb}} ; \mathrm{V} \mathrm{f} .8^{\mathrm{rb}}$ ).

27 Longpré 1926, p. 897: “... et l' auteur du Liber de causis, dont Thomas d'York fait un chrétien ..." Loris Sturlese was more careful in editing the 18th proposition of the Expositio super Elementationem theologicam Procli by the German Dominican Berthold of Moosburg, where this passage from the Sapientiale is literally quoted: the Liber de causa prima is not identified in Berthold's apparatus fontium, and the source is indicated as not found (non inveni) by the editor. See Berthold of Moosburg, Expositio super Elementationem theologicam Procli, Prop. 14-34, prop. 18B, p. 48, l. 157-16o and note 28. Hudry 1997, p. XLVII identifies the Liber de causa prima with the Liber viginti quattuor philosophorum, since the Liber de causa prima "parfois désigne le Liber XXIV philosophorum en Angleterre." This identification, however, does not seem to be convincing to Antonella Sannino (see Sannino 2008, p. 262).

28 William of Alvernia, De Trinitate, 6, p. 40, l. 76-79: Eodem modo nullo existente fonte essendi, non erit et fluens esse. Si enim totum esset fluens, non haberet, unde flueret. Nec enim a se ipso flueret, nec per modum circuli, nec per modum infiniti. 
Nam videtur, quod sit innominabilis tam secundum sapientes mundi quam sapientes Dei.

Primo per hoc quod dicitur De causis prop. 7, quod causa prima superior est omni narratione, quoniam non cadit sub sensu aut ymaginatione, cogitatione aut intelligentia, et per consequens nec sub loquela, sicut dicit ibi Commentator. Ad idem agit quod dicitur prop. 23, quod causa prima est super omne nomen quod nominatur, ad quem non pertinet diminutio neque complementum, sicut dicit divinus Paulus, quod est super omne nomen, quod nominatur in hoc seculo aut in futuro. Unde divinus Dionysius De divinis nominibus cap. 1 dicit ipsum super omne nomen et intellectum, quia cogitationes omnium existentium finem habent, ipse autem infinitus est, et propter hoc nullo nomine nominatur. ${ }^{29}$

Moreover, in the seventeenth chapter of the first book, Thomas declares that the philosophers have identified God with the First Cause and calls attention to De causis:

Deus est prima causa, unus omnium queque sunt, queque videntur esse princeps et origo. [...] Iam enim nominaverunt ipsum philosophi causam primam, sicut manifestum est per plures propositiones De causis et per rationes primi, quas supra dixi. ${ }^{30}$

Therefore, it seems that Thomas was persuaded that the author of the propositions was a philosopher. However, he was not convinced of the attribution of the Liber to Aristotle, as was commonly held in the thirteenth century, until Thomas Aquinas discovered the real origin of this text: in the Sapientiale, the propositions are always ascribed to an anonymous author and the name of Aristotle is never mentioned as the possible author of De causis.

As for the authorship of the commentaries, Thomas is even more hesitant: in book I, II, IV and VI, Thomas speaks of an unspecified Commentator. In book III and VII, the Commentary is clearly considered as a work of Al-Fārābī. ${ }^{31}$

\footnotetext{
29 Thomas of York, Sapientiale, I, 15 (F f. $15^{\text {rb }}$, R f. $28^{\text {va; }}$ V f. $\left.12^{\text {va }}\right)$.

30 Thomas of York, Sapientiale, I, 17 (F f. $24^{\text {va; }}$ R f. $37^{\text {ra }}$; V f. $19^{\text {va }}$ ).

31 The attribution of the Commentary to Al-Fārābī is well-documented by the manuscript tradition of De causis. Among the mss. described by Pattin, eleven mss ascribe the Commentary to Al-Fārābī. See Pattin 1966, p. 101-12o, mss. n. 5, 7, 8, 23, 27, 53, 61, 66, 67, 77, 78 . Berthold of Moosburg was also convinced that Al-Fārābī was the author of the Commentary to De causis. See Berthold of Moosburg, Expositio super Elementationem theologicam Procli, Prop. 16o-183, prop. 166B, p. 49, 1. 89-9o: Secundo ostenditur idem per Alpharabium super 3 o prop. De causis.
} 


\section{Sapientiale De causis (Proposition) De causis (Commentary)}

\begin{tabular}{lll}
\hline I book & Auctor & Commentator \\
II book & Auctor & Commentator \\
III book & Auctor & Alfarabius \\
IV book & Auctor & Commentator \\
V book & no quotation & no quotation \\
VI book & Auctor & Commentator \\
VII book & Auctor & Alfarabius \\
\hline
\end{tabular}

Another problem is closely related to this changing identification of the author of the Commentary. Thomas is quite precise in quoting his sources. With regard to the Liber de causis, he usually indicates the number of the proposition that he is referring to. However, the way in which he quotes the propositions of the Liber de causis after the fourth proposition changes. As is well known, most manuscripts containing the Latin version split the long proposition four into two different propositions, so that these manuscripts present an internal division of the text into thirty-two chapters or propositions, whereas the Arabic original comprises thirty-one propositions.

As the chart below shows, in book I and VI, Thomas refers to the text with an internal partition that is closer to the Arabic original, i.e., to a text composed of thirty-one propositions, whereas in book III and VII, he constantly refers to a text consisting of thirty-two propositions.

\section{Sapientiale, book I \\ De causis}

... sicut dicitur super propositionem De causis prop. 17 Prop. 17(18)

... manifestat propositio De causis $21 \quad$ Prop. 21(22)

... que scribitur De causis $12 \quad$ Prop. 12(13)

... declaratur prop. $14 \quad$ Prop. 14(15)

\section{Sapientiale, book III De causis}

... sicut habetur De causis prop. 6 Prop. $5(6)$

... iterum prop. $20 \quad$ Prop. 19(20) 
(cont.)

Sapientiale, book III De causis

\begin{tabular}{ll}
... sicut dicitur prop. 24 & Prop. 23(24) \\
... ex prop. 7 & Prop. 6(7) \\
... ex prop. 25 & Prop. 24(25) \\
\hline
\end{tabular}

In book III, in which Thomas quotes De causis as being composed of thirty-two propositions and the Commentary as being written by Al-Fārābī, Thomas also attributes a literal quotation from Nicholas of Amiens' De articulis fidei to De causis. ${ }^{32}$

To explain such variations, one might think that Thomas of York had two manuscripts of the Liber de causis at his disposal: one that was structured in thirty-one axioms with an anonymous Commentary, and another one presenting an internal division into thirty-two propositions, a Commentary to each proposition ascribed to Al-Fārābī, and transmitting the text of De articulis fidei by Nicholas of Amiens. The latter possibility, however, is not completely unfounded, since the Liber de causis did not only circulate within the Aristotelian corpus, but was often linked to the Liber XXIV Philosophorum, ${ }^{33}$ the Liber de intelligentis and De articulis fidei of Nicholas of Amiens. Of the manuscripts that bear the text of De articulis fidei, I have identified eighteen manuscripts, which also transmit the text of the De causis. ${ }^{34}$

32 See Thomas of York, Sapientiale, III, 8 (F f. 145 ${ }^{\mathrm{va}}$; R f. $15^{\mathrm{va}}$; V f. $76^{\mathrm{rb}}$ ): Omnino enim alia est causa a causato, secundum quod dicit propositio De Causis 8: nichil est causa sui. See Nicholas of Amiens, Ars fidei catholicae, p. 81, l. 16.

33 According to Hudry 1992, p. 63, nine of the twenty-three manuscripts which contain the Liber XXIV philosophorum also include the Liber de causis.

34 1. Ms Evreux, Bibl. Municipale, 79 (see Taylor 1983, n. 44). 2. ms Firenze, Bibl. Medicea Laurenziana, Ms. Plut. 83.27 (Taylor 1983, n. 47). 3. Ms Madrid, Bibl. Nacional, 489 (Taylor 1983, n. 85). 4. Ms Oxford, Balliol College Lib., 112 (Taylor 1983, n. 111). 5. MS Oxford, Balliol College Lib., 232 (Taylor 1983 n. 112). 6. Ms Oxford, Bodleian Library, Auct. F.5.28 (Taylor 1983, n. 116). 7. Ms Oxford, Magdalen College Library, 192 (Taylor 1983, n. 121). 8. Ms Oxford, Merton College Library, 140 (Taylor 1983, n. 122). 9. Ms Paris, Bibl. Nationale, Lat. 6506 (Taylor 1983, n. 144). 10. MS Paris, Bibl. Nationale, Lat. 16082 (Taylor 1983, n. 154). 11. Ms Paris, Bibl. Nationale, Lat. 16084 (Taylor 1983, n. 156). 12. Ms Reims, Bibl. Municipale, 864 (Taylor 1983, n. 164). 13. MS Tours, Bibl. Municipale, 247. 14. MS Uppsala, Universitetsbibl., Ms. C.595 (Taylor 1983, n. 188). 15. Ms Città del Vaticano, Bibl. Apostolica Vaticana, Vat. Lat. 1041 (Taylor 1983, n. 200). 16. Ms Città del Vaticano, Bibl. Apostolica Vaticana, Vat. Lat. 2081 (Taylor 1983, n. 203). 17. Ms Zagreb, Metropolitanbibl., Mr. 97 (Taylor 1983, n. 237). 18. The 
The presence of the Liber in the Sapientiale is not constant. Even though it is possibile to find quotations in every book - the only exception being the very short fifth book-, the highest number of quotations are concentrated in the first, the third and the seventh book.

This is, of course, far from being a coincidence, as a quick look at the structure of the Sapientiale reveals.

The first part of the work, which corresponds to the entire first book, deals with God as creator and with God's properties. In this part, Thomas quotes the Liber de causis thirty-seven times.

The second part of the Sapientiale comprises the following five books (books II-VI) and examines being insofar as it is being. The second book deals with creation, introduces the problem of the first principles - that Thomas identifies with matter, form and privation - and ends with a treatise on the transcendental properties of being which are convertible with it, namely unum, bonum etverum. In this book, there are eight explicit quotations from the De causis.

Arguments of the third book concern the divisions of being and the doctrine of the causes. In this part, we find a large number (thirty-seven) of quotes from De causis.

The fourth, fifth and sixth books discuss being as substance and as accident and treat the doctrines of the categories and the universals. The presence of the pseudo-Aristotelian Liber is scarce here and limited to six quotations.

Thomas intended the third part of the Sapientiale to be divided into two books. We only have the first one, which concerns the world, the intellects and the soul. In this book (book VII), a large number of quotations (sixteen) are used to support Thomas' point of view regarding separate intellects.

It is therefore possible to locate three main fields in which the influence of De causis is especially relevant: (1) the properties of God, the doctrine about (2) the causes and (3) the intellects.

MS Oxford, Bodleian Library, Digby 67 (Taylor 1983, n. 118) transmits just a fragment of the Ars catholicae fidei after De causis and the Liber XXIV philosophorum (see Hudry 1997, p. LXVI). 
From De causis, Thomas primarily borrows the identification of God with the First Cause, ${ }^{35}$ which is not only the cause of everything, but also more powerful than each subordinate cause that succeeds it. The metaphysical primacy and the causal priority of the remote First Cause is constantly maintained in the Sapientiale by quoting the first proposition of De causis. ${ }^{36}$

Thomas of York, following the intention of De causis, puts great emphasis on the exclusive condition of the causal power of the First Cause, namely the power to create, which is a power that requires nothing while everything else requires it (see Appendix 2, n. 14-16; 30-31).

The causality of the First Cause extends uniformly throughout the entire hierarchy of beings (Appendix 2, n. 17-18). God's causality, indeed, expands over all beings that are.

He is also the cause of the causal power of the intellects. The First Cause (i.e., God) truly is virtus virtutum, per quam est virtus in omnibus intelligentiis, ${ }^{37}$ since every power depends, as De causis says, on the First Power: "all powers that are infinite depend upon a First Cause, whose infinite power is the cause of theirs." 38 The intellects and their causal powers, although they are infinite in a certain sense (virtus intelligentie non est infinita nisi inferius), are created and thus dependent upon the First Cause, which has no limit (virtus vero primi infinita est inferius et superius) (see Appendix 2, n. 35-36).

The complexity of the causal connections and the omnipresence of the First Cause in everything does not weaken the unique transcendent status of the First Cause. This is so for four reasons, which Thomas borrows from De causis.

1. The transcendence of the First Principle is so absolute that no-one can grasp it: no name can designate it, no description can be made of it. The First Cause can be known not in itself (secundum suam substantiam est innominabilis): it can only be disclosed by its effect (ex effectu est nominabilis) and signified by the other causes, which receive the influence of the First Cause (non narratur nisi propter causas, que illuminantur a lumine cause prime) (see Appendix 2, n. 2, 5-10). ipsum philosophi causa primam, sicut manifestum est per plures propositiones De causis.

36 For an overview of the philosophical content of De causis, see D'Ancona 2014, p. 141-157.

37 Thomas of York, Sapientiale, I, 31 (F f. $37^{\mathrm{vb}}$; R f. $49^{\mathrm{rb}} ; \mathrm{Vf} .3 \mathrm{O}^{\mathrm{ra}}$ ).

38 See D'Ancona 2014, p. $15^{2}$. 
2. God as First Cause creates and rules every created being, but he remains discrete (discretus) and unmixed (impermixtus) in His own unity (Appendix 2, n. 12, 65-66). Although the First Cause is related to all of its effects in the same way, the effects are not related to the First Cause in the same way (Appendix 2, n. 67-68).

3. As the cause of every power, God is said to be absolutely perfect (perfectissimus), since His substance and power are both eternal (Appendix 2, n. 69).

4. The First Cause is the only simple substance (substantia nullo modo in compositione et simpliciter simplex ${ }^{39}$ ), whereas all creatures are more or less composite, their composition being dependent on their proximity to the absolutely simple (compositio in hoc simplici est diversa secundum appropinquationem differentem ad simpliciter simplex $\left.{ }^{40}\right)$. A long chapter of the third book (cap. 28) is devoted to this problem (in ponendo rationes seu descriptiones eius, quod est simplex, et proprietates, ex quibus manifestum est quid simplex et quid non, et quid summe simplex et quidnon summe simplex). In this chapter, the influence of De causis is particularly prominent, as thirteen explicit quotations testify (Appendix 2, n. 70-82).

Quoted more than twenty-one times within the Sapientiale, the first proposition of De causis plays a special role not only in the description of God as First, transcendent Cause, but also in explaining causality in general and the relationships between the First and the secondary causes. The first part of the so-called Sermo de causis $^{41}$ is devoted to this problem.

In chapter eleven of the third book, Thomas deals with the question whether the First Cause is the immediate agent in every action or whether in any action there is an intermediary (an in omni actione, non tantum creationis sed etiam eductionis, sit ipse primus immediate agens, an in aliqua actione agat per medium $\left.^{42}\right)$.

\footnotetext{
39 Thomas of York, Sapientiale, III, 29 (F f. 175 ${ }^{\mathrm{va}}$; R f. $178^{\mathrm{vb}}$; V f. $\left.103^{\mathrm{rb}}\right)$.

40 Thomas of York, Sapientiale, III, 29 (F f. $175^{\mathrm{va}}$; R f. $178^{\mathrm{vb}}$; V f. $103^{\mathrm{rb}}$ ).

41 The so-called Sermo de causis comprises the chapters 8-19 of the third book (F f. $145^{\mathrm{va}}$

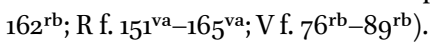

42 Thomas of York, Sapientiale, III, 11 (F f. $149^{\mathrm{va}}$; R f. $155^{\mathrm{rb}} ; \mathrm{Vf}$. $\left.8 \mathrm{o}^{\mathrm{ra}}\right)$. An analysis of this text is to be found in Treserra 1929, p. 48-49 and Reilly 1953. The text is quoted almost verbatim by Berthold of Moosburg in his Commentary to Proclus (see Berthold of Moosburg, Expositio
} 
Thomas introduces the discussion of this problem with the statement that God is by necessity the efficient cause of everything. The causality of the First Cause extends over all creatures, since the First Cause is more powerfully the cause of everything than the subordinate causes (as De causis maintains), and what causes the cause also causes everything else (as Nicholas of Amiens says):

[...] cum causatum omne causam habet et omne factum factorem et omnis factor unus post unum reducitur ad factorem primum tamquam ad agentem et efficientem principalem, tunc sequitur necessario, quod ipse est efficiens omnium, et causarum et causatorum, utpote "causa prima plus influens in causata omnia quam cause secundarie." Amplius superius dictum est quod "quidquid est causa cause, est causa causati."43

After this premise, Thomas first calls attention to the opinion according to which God is the only immediate agent and the only true cause; the creature is by no means an agent but just an occasion for the causal activity of the First Cause. Thomas notes that this opinion is supported by the authority of some Christians and in particular by Augustine's statements in his De civitate Dei, ${ }^{44}$ in De Genesi ad litteram ${ }^{45}$ and in De Trinitate: ${ }^{46}$ the Creator is the sufficient and unique cause of every action; he does not admit any co-actor. This is because the Creator is close to every creature, most intimately present to them, since He alone can enter into the essence of the creature.

Et iam fuerunt aliqui, qui posuerunt ipsum immediate agere omnino et non posuerunt creaturam agentem in aliqua actione naturali, sed tantum occasionem, qua per actionem primi forma natura〈lis $\rangle$ inducitur in materia. Isti autem suam opinionem confirmare uoluerunt per sermones sapientum Christianorum, per quos uidetur, quod inductio formarum naturalium in materia attribuatur solummodo actioni creatoris, secundum quod dicit sapiens Augustinus De civitate Dei XII cap. 25. [...] Hoc videtur manifeste dicere De Trinitate III cap. 9, loquens de terre nascen-

super Elementationem theologicam Procli, Prop. 136-159, prop. 137E, p. 19, 1. 145-p. 21, 1. 211). In the apparatus fontium of Berthold's text, the indication Sapientiale v, 11 instead of III, 11 is only due to a different numbering of the books in the Florentine manuscript, which is the manuscript followed and quoted in Berthold's edition. On this problem, see Retucci 2011, p. 141-142.

Thomas of York, Sapientiale, III, 11 (F f. 149 $9^{\mathrm{va}}$; R f. $155^{\mathrm{rb}}$; V f. $\left.79^{\mathrm{vb}}-8 \mathrm{o}^{\mathrm{ra}}\right)$.

44 See Augustine, De civitate Dei, XII, 26, p. 382, l. 11-18; XXII, 24, p. 848, 1. 57-6o.

45 See Augustine, De Genesi ad litteram, viI, 22, p. 221, 1. 9-11.

46 See Augustine, De Trinitate, III, 7, n. 13, p. 141, l. 59-67; III, 7, n. 14, p. 141, l. 76-8o. 
tibus, et dicens quod "extrinsecus adhibitis motibus creanda tamen Dei virtus interius operatur," inferius dicens de bonis etiam angelis, quod semina noverunt, "et ipsa per congruas temperationes elementorum spargunt, atque ita gignendarum rerum et accelerandorum incrementorum prebent occasiones." Et infra: "Sicut in ipsa vita nostra mentem iustificando formare non potest nisi Deus," "ita creationem rerum visibilium Deus interius operatur." Ex quo videtur, quod sicut in generatione spirituali creatura tantum est occasio, ita in generatione naturali. Istam eandem positionem muniunt rationibus per hoc, quod volunt creatorem intimiorem esse omni creature quam ipsam sibi, et propter hoc necesse est, quod intercipiatur tamquam agens inter omnem creaturam agentem et actam. Amplius solus ipse ingredi videtur et penetrare essentiam creature, quare solus videtur perfecte operari in creatura. Preterea sufficiens principium actionis est ipse creator; quare in genere actionis non admittit socium. ${ }^{47}$

However, this doctrine is clearly rejected by the philosophers, especially by Averroes.

Sciat igitur lector in principio hanc positionem a philosophia reprobatam, secundum quod habetur ab Averroe super Ix Metaphisice cap. 4:48 "Moderni-inquit—ponunt unum agens omnia entia sine medio, scilicet Deum. Et ista—dicit—opinio est valde extranea a natura hominis. Et qui recipiunt huiusmodi $\langle$ opinionem $\rangle$, non habent cerebrum habile naturaliter ad bonum." Huius autem opinionis desctructio patet per multa. ${ }^{49}$

47 Thomas of York, Sapientiale, III, 11 (F f. $149^{\text {va-b; }}$ R f. $155^{\text {rb }}$; V f. $80^{\text {ra }}$. According to Reilly 1953 , p. 227, Thomas' opponent here clearly is William of Auvergne, as Reilly tries to demonstrate by quoting William's De universo and De trinitate. However, we must be very careful with this association. William, in this exact context, does not at all use Augustine to support his own doctrine. Moreover, in a recent study on William's doctrine of causality, Antonella Sannino convincingly argues that for William, created substances are true agents that can contribute to God's causal activity as media causationi (see Sannino 2004, p. 46-47). Also for Teske 1989, p. 22-23 "secondary causes have the power to act; what they do not have is an intrinsic necessity that would withdraw them from God's control." A possible (Christian) supporter of the position criticized by Thomas could actually be Peter Lombard, who quotes the long passage from De Trinitate III to conclude that sicut iustificationem mentis, ita creationem rerum solus Deus operatur, licet creatura exterius serviat (See Peter Lombard, Sententiae in IV libris distinctae, II, 7, cap. 8-9, p. 363, l. 18-p. 364, l. 11).

48 See Averroes, Super Metaphysicam, IX, comm. 7, p. 38, l. $39-45$.

49 Thomas of York, Sapientiale, III, 11 (F f. $149^{\mathrm{vb}}$; R f. $155^{\mathrm{rb}}$; V f. $8 \mathrm{o}^{\mathrm{ra}}$ ). 
Thomas then alludes to a second, more persuasive opinion, according to which every natural agent is the proper cause of what is generated (natura non tantum est occasio, sed causa per suam actionem naturalem in generatione eorum, que fiunt).

For this viewpoint, shared by some sapientes mundi (i.e., some philosophers), such as Averroes, Aristotle and Maimonides, the production of particular beings by educing their forms from the potency of matter is due to an eductor, which is of the same genre and close to the educed being. But since the First Cause, existing outside every genus, has nothing in common with created beings and is related to effects always in the same way (as De causis asserts; see Appendix 2, n. 59), the differences present in the effects must derive from the differences in the causes. This means: beyond God, there are other secondary causes, which are responsible for the differences present in created natures:

Ex hiis igitur habitis necessario sequi videtur, quod potentia naturalis, quodque est principium generationis, vere sit agens et veraciter formam inducens, et non tantum inducende occasionem prestans. [...] Preterea sicut dicit Rabbi Moyses cap. 83, ${ }^{50}$ "omne, quod exit de potentia ad actum, habet extractorem" sui generis cum eo, idest extracta. Alioquin quidlibet extraheret quodlibet, vel ad minus casualis esset extractio, ut esset convenientia inter extrahentem et extractum in forma. Prima autem causa nullius generis est cum alio, cum se habeat secundum unam dispositionem ad omnia causata, secundum quod dicitur De causis. Quare, ut fiat differentia extractorum in singulis generibus, necesse est ut preter ipsum sint extractores eiusdem generis cum extractis. ${ }^{51}$

The creature is thus not an occasion for the First Cause to induce forms into matter, since it acts as a true agent beyond the First Cause.

Igitur per viam illam patet, quod natura agens est sic agens, quod habet formam apud se eius, quod fieri debet. Omnis autem sic agens est agens non sicut agens per occasionem, sed sicut est verus agens, inter quem et actum est essentialis comparatio inquantum huiusmodi. Quare preter agentem primum est creatura vere agens. [...] Hiis igitur et consimilibus sermonibus liquet, quod nature non absolvuntur ab actionibus suis in

$5^{\circ} \quad$ See Maimonides, Dux neutrorum, II, 5 , ed. Parisiis 1520, f. $42^{\mathrm{v}}$.

$5^{1}$ Thomas of York, Sapientiale, III, 11 (F f. $\left.149^{\mathrm{vb}}-15^{\mathrm{O}}{ }^{\mathrm{ra}} ; \mathrm{R} \mathrm{f.} 155^{\mathrm{va}} ; \mathrm{V} \mathrm{f.} 8 \mathrm{o}^{\mathrm{rb}}\right)$. 
eductionibus formarum de materiis, sed quod sunt agentes medii extractores sive eductores, et non tantum occasionum largitores. ${ }^{52}$

For Thomas, the interpretation given to Augustine by the supporter of the first position is, therefore, wrong. Augustine's real intention was to sustain God's genuine contribution in the secondary causality as well as to affirm His primacy in the production of effects in nature, according to what De causis says in the first proposition. This means that an authentic interpretation of Augustine's words is possibile only in the light of De causis.

Scito igitur, quod intentio Augustini in sermonibus suis, cum dicit Deum formatorem et formas induci per ipsum in inferioribus, est non excludere ipsum ab operibus secundarium agentium, immo potius attribuere ei principalitatem, cum causa primaria plus influat, secundum quod dictum est superius. [...] Et hec est via respondendi ad omnes auctoritates, que videntur attribuere formationem rerum immediate creatori. ${ }^{53}$

Hence, Thomas is able to maintain the secondary causality while at the same time safeguarding the efficacy of the First Cause over its effects. God's primacy over its creatures does not imply the negation of a legitimate secondary causation in nature. On the contrary, even if the First Cause is sufficientissimus agens, it wants to have co-actors (quamvis sit sufficientissimus agens, tamen vult habere cooperatores).${ }^{54}$

The first proposition of De causis plays a special role in Thomas' doctrine and his vehement criticism of a kind of Christian occasionalism. ${ }^{55}$ On the basis of De causis, Thomas is able to combine the primacy of the First Cause with the efficacy of the secondary causes. ${ }^{56}$

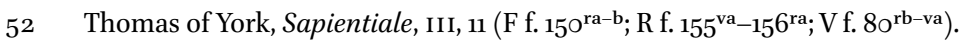

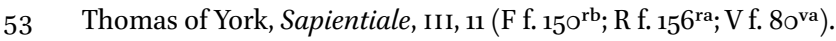

54 Thomas of York, Sapientiale, III, 12 (F f. $15^{\mathrm{vb}}$; R f. $15^{\text {rb }}$; V f. $81^{\mathrm{ra}}$ ).

55 As Reilly has already noted (see Reilly 1953, p. 226), Thomas of York is quite close to Thomas Aquinas concerning this specific topic, especially regarding Thomas's statements in his Commentary on the Sentences II, 1, 1, 4 and in the Summa contra Gentiles, III, 69. According to Freddoso 1994, p. 132 (who actually quotes Iglesias 1946, p. 102), Thomas Aquinas "was the first scholastic doctor to treat this question in a special place, i.e., detached from the problem of the cause of sin, and to extend it explicitly to all natural operations, whether they be operations of nature or of the will." This should not be the case, as the texts from the Sapientiale here examined have shown. On Occasionalism and Aquinas' criticism of it, see Perler, Rudolph 200o, p. 127-156.

$5^{6}$ The same topic is present also in book I, 17 (see Appendix 2, n. 14-16). 
Thomas then describes in detail how the secondary agents work. He does so in a long passage, which is quoted verbatim by Berthold of Moosburg in his Commentary on Proclus' Elements of Theology. Berthold completely agrees with Thomas of York on the doctrine of the causality of the secondary causes. Furthermore, Berthold notes how Thomas' doctrine is close to that one of Proclus. Thus, instead of implicitly quoting De causis-as Thomas does-, Berthold introduces two explicit quotations from the Elementatio theologica in order to confirm Thomas' position.

Thomas of York, Sapientiale III, 13

(F f. 151 ${ }^{\text {vb }}$; f. 157 ${ }^{\text {rb }}$; f. 81 ${ }^{\text {vb }}$ )

Hii enim agentes quattuor operationem habent, communem et specialem.

Communem quoniam in singulis operibus nature concurrunt omnium actiones, sicut supra dictum est, quomodo omnis forma inducitur in materia per omnes causas medias usque ad primam, et sic per ipsam plus effluentem (cf. De causis, 1).

\section{$[\ldots]$}

Habent et specialem, sicut superior respectu inferioris. Nichil enim habet inferior, quod non superior, instar ordinum angelicorum, sicut ponit sapientia Christianorum; habet tamen superior proprium, quod non habet inferior, uel ad minus non in eadem plenitudine. Ideo actio uirtutis elementi aut elementati actio est uirtutum omnium superior.
Berthold of Moosburg, Expositio prop. 151D (p. 137, l. 184-p. 138, l. 193)

De primo sciendum, quod ipsorum deorum quaedam operationes sunt communes, quaedam speciales.

Communes inquantum in singulis operibus naturae concurrunt omnium actiones: omnis enim forma inducitur in materia per omnes causas medias essentialiter sibi subordinatas usque ad prime bonum inclusive. "Omne enim, quod a secundis producitur, et a prioribus et causalioribus producitur eminentius" per $5^{6.57}$

Speciales vero sive proprie operationes sunt, quas habent superiora respectu inferiorum: quidquid enim operatur inferius haec et operatur superius, sed non e converso. Et de istis operationibus dicitur, quod "omnis deus a se ipso orditur propriam operationem" per 131.58

57 Proclus, Elementatio theologica, p. 30, 1. 1-2.

$5^{8}$ Proclus, Elementatio theologica, p. 66, l. 1. 
According to Thomas, the metaphysical hierarchical continuity from the highest down to the lowest level of reality is ensured by the existence of intermediate causes, and through them by the primacy of the First Cause, as De causis affirms. The chain of causal dependence reaches from the divine mind to the lowest realm of material beings: the separate intellects receive the forms of everything present in the divine mind in order to move the inferior bodies and to imprint the forms observed in the exemplar into matter:

Ex hiis autem omnibus una cum predictis scire poteris, quomodo est existentia formarum etiam naturalium in materia. Nam cum natura illa inferior non mota non movetur, movetur autem a corporibus celestibus, et corpora celestia $a b$ intelligentiis, et intelligentie $a b$ arte et secundum artem, quam aspiciunt in mente divina, sicut dictum est, tunc intelligentie inspiciunt formas omnium inferiorum in eadem arte prima, secundum quam et movere debent corpora inferiora, ut imprimatur forma, que inspecta est in suo exemplari, in materia. Ex hoc autem aspectu speciei in mente divina exprimitur ipsa forma in intuitu inspicientis, quam quidem speciem secundum eandem artem, prout possibile est, exprimit in motibus celorum et per ipsos in potentiis materie, in qua, cum est ista forma in potentia naturali, natura mota taliter movetur ad forme expressionem in ipsa materia per iugem et indesinentem expressionem eiusdem speciei ab arte divina in aspectu intelligentie, et ab acie intelligentie in motibus et celorum virtutibus, et per ipsas in potentiis materie, quarum expressionum singule, si vel ad momentum desisterent, numquam forma exprimeretur in materia. ${ }^{59}$

This doctrine is maintained by Plato, preserved by Avicebron, but strongly rejected by Aristotle, who is more interested in the exterior appearance than in the real meaning of Plato's argument.

Ex hiis igitur patet, sicut videtur, quid impugnavit Aristoteles in sermonibus Platonis et aliorum sapientum, quia sermonem potius quam intellectum, more suo volentes tractatores sapientie non sentire recte

59 Thomas of York, Sapientiale, II, 27 (F f. $86^{\text {ra-b; }}$ R f. $95^{\text {va-b; }}$ V f. $63^{\text {ra-b}}$ ). Berthold quotes this passage verbatim (see Berthold of Moosburg, Expositio, Prop. 145F, ed. Retucci, p. 86, l.158p. 87, l. 173), but lays more emphasis on the distinction between the separate intellects and the motors of heavenly bodies (in line with Dietrich of Freiberg, as demonstrated by Sturlese 1978). On the other hand, Thomas accepts the same distinction (see the chapters 10-15 of book VII of the Sapientiale, Appendix 2, n. 89-102). 
tantum, sed et loqui. Et ideo multotiens impugnavit sermonem Platonis et non intellectum. ${ }^{60}$

This progressive realization through the chain of causes relies on two elements: first, the separate intellects, and second, the Platonic ideas. Both doctrines are supported - within the Sapientiale - with the aid of quotations from the De causis. Both doctrines are, according to Thomas, completely rejected by Aristotle.

Thomas dedicates six chapters of book seven to the doctrine of the intellects. ${ }^{61}$ Thomas has a clear view regarding the different positions concerning the existence of the separate substances. Plato and his followers speak of good daemons, in perfect accordance with Christian wisdom and its teaching about the angels. Aristotle, on the contrary, firmly denies the existence of any abstract substance that is not responsible for movement. ${ }^{62}$

Thomas clearly prefers Plato and Christian wisdom: in addition to the intermediate substances responsible for the movement of the heavenly bodies and for the production of the natural things, he maintains the existence of other intermediary substances (namely the angels of the Christian wisdom and the daemons of the Greek tradition), which are totally separated and collaborate in the divine rule of the voluntary acts of man:

6o Thomas of York, Sapientiale, II, 27 (F f. $86^{\text {ra; }}$ R f. $95^{\text {va }}$; $\mathrm{V}$ f. $63^{\text {ra }}$ ).

61 Thomas of York, Sapientiale, VII, 10-15.

62 Thomas of York, Sapientiale, VII, 10 (F f. $224^{\text {ra-b}}$; R f. $249^{\text {rb }}$, V f. $\left.18 \circ^{\text {ra-b}}\right)$ : Scito igitur in primis secundum antiquorum opinionem, quod universum spirituale separatum et absolutum dividitur in tres partes. Quarum prima est de intelligentiis, sicut posuerunt seu nominaverunt eas Aristoteles et sequaces eius. Secunda pars est de substantiis, quas nominaverunt Plato et imitatores eius calodemones, sapientia vero Christianorum nominat eos angelos bonos et sanctos. [...] Secundam etiam partem visus est potius destruere quam asserere Aristoteles, cum dicat XI Prime Philosophie non esse substantiam abstractam, que non moveat. [...] Et propter hoc in primis est persuadendum, quod est aliqua substantia separata a corpore et appendicibus eius, quam non sit necesse motricem esse corporis alicuius determinati, speculantem faciem primi et adimplentem imperium eius. Et hoc est ostendere angelum esse, secundum quod dogmatizat sapientia Christianorum, cum dicit angelos semper videre faciem Patris, qui in celis est, et quod ipsum desiderant semper prospicere. Quamvis, ut dixi, Aristoteles visus est hoc negare [...]. 
Et propter hoc, sicut sunt substantie medie in productione naturalium, quas dicunt motores celorum, sic necesse est ad providentie expletionem, ut sint substantie medie ad eorum, que sunt hominum, hoc est voluntariorum, idest eorum actuum, quorum voluntatis principium est ordinatum cognitioni. [...] Et propter hoc intervenit Deus humanis rebus. Et quoniam hic connexus nature est per medias substantias, et ideo, ne homines a divinitate repellantur, necesse est secundum eundem (scil. Apuleius), quod sint quedam divine medie potestates, quas Greci demones vocant. Quare ex cura, quam habet Deus de hominibus, preter alias rationes necessarie sunt medie substantie inter ipsum et homines, non tantum ille, quas dicunt sapientes celorum motores, sed ille etiam, quas dicit sapientia Christianorum angelos. ${ }^{63}$

To prove the existence of such substances, Thomas explicitly quotes De causis in fourteen occasions. Thus, by quoting seven different propositions from the Liber, ${ }^{64}$ Thomas of York neutralizes Aristotle's objections against the doctrine of the separate substances (Appendix 2, n. 89-102).

\section{Platonic Ideas}

Thomas sees the same philosophical battle lines when it comes to the doctrine of the ideas: there are two opposite fronts, namely the right position, defended by Plato and Augustine, and the wrong one, as represented by Aristotle. ${ }^{65}$

According to Thomas, all Aristotelian objections against the Platonic ideas result from a naive misinterpretation: Aristotle equivocat in nomine universalis, since he considered the universal forms just as abstractive ideas, i.e., as the result of a discursive thinking, whereas Plato understood them as transcendent Ideas, according to which everything is created:

"Universale quidem et totum non intelligibiliter, ut universale logicum, sed intellectualiter. Universale quidem subsistens multis separabiliter,

63 Thomas of York, Sapientiale, VII, 12 (F f. 228 ${ }^{\text {rb-va; }}$ R f. $253^{\text {rb }}$; V f. $184^{\text {ra }}$ ).

64 Prop. 16(17), 6(7), 20(21), 30(31), 29(30), 27(28), 1.

65 Thomas of York, Sapientiale, I, 29, in Retucci 2008(b), p. 103, 1. 7-10: Iam nunc post hoc tempus est inspicere, quae dixit Aristoteles contra Platonem, an eidem secundum veritatem contradixerit, an non, maxime cum plura eorum, quae dixit Aristoteles, impugnare videntur sententiam veram de ideis, quam tenet sapientia Christianorum una cum Platone. 
que secundum illud facta sunt." 66 Similiter et dixit ideam totum non ex partibus vel in partibus, sed ante partes. ${ }^{67}$

Against Aristotle, Thomas mounts his defense of Plato's ideal world, which is in perfect accordance with the doctrine of the Christians (tenet [scil. sententia de ideis] sapientia Christianorum una cum Platone), by explicitly quoting Eustratios of Nicea and his Commentary on the Nicomachean Ethics. The Byzantine commentator, in complete conformity with Plato and Augustine, indeed speaks of a triple esse rei: in the divine, uncreated mind, in the created intellectual being and in the matter.

Oportet te scire in principio sententiam Platonis memoria dignam, quam recitat Commentator super I Ethicorum cap. 7 et vi Ethicorum cap. 8, consonam per omnia sententie sapientis Augustini Super Genesim lib. II, cum dicit triplex esse rei, in verbo scilicet increato, in intellectuali natura creata et in materia sive in proprio esse, et quod esse primum est prius duobus sequentibus et esse secundum tertio. ${ }^{68}$

For Thomas, then, there are three kinds of form: the form which succeeds generation, i.e., the logical universal; the form which exists before the singular, created beings in the divine mind; and a third form which is present in the separate intellect and functions as intermediary between divine ideas and material reality. The existence of the latter is openly criticized by Aristotle, but maintained by Plato, whose authority is, for Thomas, supported by De causis.

Si quis opponat impossibile esse ideam, quia impossibile est destructis sensibus manere speciem et ipsa manet ipsis destructis, prout vult Aristoteles II Metaphisicae cap. 8, iam solutum est per distinctionem speciei superius datam, quod est species posterior generatione singularibus, que est universale logicum, et hec non subsistit illis destructis, sicut dicit Aristoteles, quod primis substantiis destructis impossibile est aliquod aliorum permanere, et est species prior singularibus, et hec non destruitur ipsis destructis. Et iste species in suo esse primitivo et principali sunt idee in mente divina, in esse vero secundario, ut sunt recepte in intelligentia, sunt species sive forme, quas dixit Plato medias inter ideas et res sensibiles.

66 Eustratius, In Ethicam Nicomachean commentarius, p. 69, l. 97-100; p. 69, l. 4-p. 7o, l. 21.

67 Thomas of York, Sapientiale, I, 29, in Retucci 2008(b), p. 109, l. 222-p. 110, 1. 224.

68 Thomas of York, Sapientiale, I, 29, p. 107, l. 130-135. 
Et in hoc solvuntur argumenta Aristotelis II I Metaphisice cap. 8, quibus impugnat formas medias [...]. Supra enim concessum est, quod forme abstracte sunt quodammodo per effectum in formis mediis, ut idee in mente conditoris resplendentes in intellectu faciunt ibi species illas, quas dixit Plato medias, secundum sermones, quos dixi tibi, quod "omnis intelligentia plena est formis." 69

According to Thomas, Plato and Augustine are in open contrast to Aristotle concerning the existence of these intermediate forms in the intellect, but they are close to De causis, where the existence of the universal forms in the separate intellects is clearly established.

Dico igitur tibi secundum sententiam Augustini et Platonis, quod triplex est esse rei, videlicet in mente divina, in intellectuali natura, in propria existentia; et quod esse eius in natura intellectiva, anima videlicet et intelligentia, medium est inter esse primum et tertium; et quod omnes forme, que exprimuntur in materia, prius naturaliter sunt concreate in intelligentia sive anima, quoniam natura pares sint, sicut dicit Augustinus De libero arbitrio lib. II. Et hoc est consonum propositioni De causis, que dicit quod "omnis intelligentia plena est formis" (see Appendix 2, n. 88). ${ }^{70}$

To sum up: in his defense of the ideal world, which linked the Platonic position with that of Augustine, Thomas of York explicitly quotes Eustratius of Nicea. As it has been proven by Carlos Steel, ${ }^{71}$ concerning this matter, Eustratius silently borrows the doctrine on the existence of a triplex esse rei from Proclus, prop. 67 of the Elementatio. As a result of this maze of quotations, Thomas - by quoting Eustratius and by showing his proximity to Plato, Augustine and De causisintentionally or not, concludes by assimilating De causis to its original source, namely Proclus' Elementatio theologica.

Far from accepting Aristotle as the author of De causis, as most medieval authors before Thomas Aquinas did, Thomas of York was, on the contrary, aware of an important fact: some doctrines transmitted in this text are in open conflict with Aristotle. Some doctrines defended in De causis are close to quite a different tradition, namely the tradition of Plato, Augustine and, through Eustratius of Nicea, Proclus.

69 Thomas of York, Sapientiale, I, 30 (F f. $36^{\mathrm{vb}}$; R f. $48^{\text {ra }}$; V29 $9^{\text {rb-va }}$ ).

70 Thomas of York, Sapientiale, VI, 26 (F f. $205^{\text {vaa }}$, R f. $216^{\text {rb }}$; V f. $166^{\text {rb }}$ ).

71 Steel 2002, p. 53-54. 
Thanks to a special philosophical and analytical skill, Thomas of York reveals a deep, precocious awareness that two fundamentally different alternatives characterize the philosohical tradition: Plato, Augustine, Eustratius and De causis represent the right option; Aristotle the wrong one.

The preference for the Platonic-Augustinian position some years later became the identifying issue of another author, i.e. the German Dominican Berthold of Moosburg. Hence, it is not suprising that Thomas' Sapientiale was revived 70 years after his death in Berthold's Expositio super Elementationem theologicam Procli. Berthold had the whole Sapientiale constantly at hand when writing his Commentary on Proclus: he quotes extensively and verbatim from the Sapientiale throughtout his Expositio. Berthold's defence of the Platonic view - especially with regard to the Platonic ideas (Prop. 176 and 178 ) is far from being under the influence of the other members of the so-called Deutsche Dominikanerschule, as Alain de Libera ${ }^{72}$ and Burkhard Mojsisch ${ }^{73}$ maintained. When writing against Aristotle in order to support the doctrine of the Christian and Platonic tradition (sententiam veram de ideis quam tenet sapientia Christianorum una cum Platone), Berthold just refers to Thomas of York's Sapientiale. ${ }^{4}$

72 See Libera 2005, p. 223-244; Libera 1992, p. 89-119; Libera 1981, p. 55-74.

73 See Mojsisch 1999, p. 267-281.

74 On this point, see Retucci 2008(b), p. 79-84. 


\section{Appendix $\mathbf{1}^{75}$}

\begin{tabular}{|c|c|c|}
\hline Liber de causis & Sapientiale & Appendix 2 \\
\hline prop. I & $\begin{array}{l}\text { I, 13; I, 17; I, 24; I, 36; II, 27; III, } \\
5 \text {; III, 8; III, 11; III, 12; IV, 16; IV, } \\
19 ; \text { IV, 22; VI, 15; VII, } 13\end{array}$ & $\begin{array}{l}\text { n. } 4 ; 14 ; 30 ; 37 ; 39 ; 46-48 ; 5 \circ \text {; } \\
58 ; 6 \circ ; 61 ; 83-86 ; 102\end{array}$ \\
\hline comm. I & I, 17; I, 24; II, 27; III, 8 & n. $15 ; 16 ; 31 ; 40 ; 49$ \\
\hline prop. IV & II, 31; II, 33 & n. $41 ; 45$ \\
\hline comm. IV & II, 31 & n. $42-44$ \\
\hline prop. v(VI) & I, 4; I, 15; I, 23; III, 8 & n. $2 ; 5 ; 8 ; 27 ; 5^{1}$ \\
\hline comm. v(VI) & I, 4 ; I, 15; I, 16; III, 8 & n. $1 ; 6 ; 10 ; 52 ; 53$ \\
\hline prop. vi(VII) & I, 12; III, 28; VII, 1O; VII, 12 & n. $3 ; 73 ; 91 ; 100$ \\
\hline comm. VI(VII) & VII, 12 & n. 99; 101 \\
\hline prop. VIII(IX) & I, 22; I, 23 & n. $23 ; 26$ \\
\hline prop. $\mathrm{IX}(\mathrm{x})$ & $\begin{array}{l}\text { I, 23; I, 29; I, 30; II, 27; III, 28; } \\
\text { VI, 26; VII, } 18\end{array}$ & n. $24 ; 33 ; 34 ; 38 ; 82 ; 88 ; 103$ \\
\hline prop. XII(XIII) & $\mathrm{I}, 22$ & n. 19 \\
\hline comm. XII(XIII) & I, 22 & n. 20 \\
\hline prop. XIV(Xv) & I, 22 & n. 21 \\
\hline $\operatorname{comm} \cdot \mathrm{XIV}(\mathrm{XV})$ & I, 22 & n. 22 \\
\hline prop. XV(XVI) & $\mathrm{I}, 31$ & n. 35 \\
\hline $\operatorname{comm} \cdot \mathrm{XV}(\mathrm{XVI})$ & I, 31 & n. 36 \\
\hline prop. XVI(XVII) & VII, 10 & n. 89 \\
\hline comm. XVI(XVII) & VII, 10 & n. 90 \\
\hline prop. XVII(XVIII) & I, $17 ; \mathrm{I}, 23 ; \mathrm{III}, 15$ & n. $18 ; 25 ; 62$ \\
\hline comm. XVII(XVIII) & I, 16; I, 17; III, 15 & n. $11 ; 17 ; 63$ \\
\hline prop. XVIII(XIX) & $\mathrm{I}, 23$ & n. 28 \\
\hline prop. $\mathrm{XIX}(\mathrm{XX})$ & I, 17; III, 8; III, 25 & n. $12 ; 54 ; 65$ \\
\hline comm. XIX $(\mathrm{Xx})$ & III, 8; III, 25; VII, 23 & n. $55 ; 66 ; 104$ \\
\hline prop. $\mathrm{Xx}(\mathrm{XXI})$ & I, 23; I, 25; III, 25; VI, 2O; VII, 10 & n. $29 ; 32 ; 64 ; 87 ; 92$ \\
\hline comm. $\mathrm{xx}(\mathrm{XXI})$ & VII, 10 & n. 93 \\
\hline prop.XXI(XXII) & I, $15 ;$ I, $16 ;$ I, 17 ; III, 8 & n. $7 ; 9 ; 13 ; 56$ \\
\hline prop.XXIII(XXIV) & III, 8; III, 11; III, 25 & n. $57 ; 59 ; 67$ \\
\hline comm. XXIII(XXIV) & III, 25 & n. 68 \\
\hline
\end{tabular}

75 In this chart as well as in the analysis above I take just explicit or literal quotations into consideration. Implicit or not literal references to the Book of Causes have been neglected. 
(cont.)

\begin{tabular}{|c|c|c|}
\hline Liber de causis & Sapientiale & Appendix 2 \\
\hline prop. $\mathrm{XXIV}(\mathrm{XXV})$ & III, 28 & n. $75 ; 78$ \\
\hline comm. XXIV(XXV) & III, 28 & n. 77 \\
\hline prop. $\mathrm{XXV}(\mathrm{XXVI})$ & III, 28 & n. 79 \\
\hline comm. $\operatorname{xXV}(\mathrm{XXVI})$ & III, 28 & n. 81 \\
\hline prop. XXVII(XXVIII) & III, 28 & n. 72 \\
\hline comm. XXVII(XXVIII) & III, 28; VII, 12 & n. $74 ; 98$ \\
\hline prop. XXVIII(XXIX) & III, 28 & n. $70 ; 76 ; 80$ \\
\hline comm. XXVIII(XXIX) & III, 28 & n. 71 \\
\hline comm. XXIX(XXx) & VII, 11 & n. $96 ; 97$ \\
\hline prop. $\mathrm{xxx}(\mathrm{xxxI})$ & III, 27; VII, 11 & n. $69 ; 94$ \\
\hline comm. $\mathrm{xxx}(\mathrm{xxxI})$ & VII, 11 & n. 95 \\
\hline
\end{tabular}




\section{Appendix 2: References to the Liber de Causis in Thomas of York's Sapientiale}

\section{Sapientiale, LIBER I}

1. $\quad$ Cap. $4\left(F\right.$ f. $5^{\mathrm{ra}} ; R$ f. $17^{\mathrm{rb}} ; V$ f. $\left.5^{\mathrm{ra}}\right)$-Liber de causis, v(vI $), 61$, p. $148,1.44^{-}$ 48

Amplius, infinitum non est ab intellectu determinatum, quia finitum non determinat infinitum, sicut habetur ab Aristotele II Metaphysice cap. 2 et Averroe in eodem; quare, cum ipse sit infinitus, non est ab intellectu determinatus, quare nec apprehensus. Nihil enim apprehenditur ab intellectu, quod ab eodem non determinatur; quare non est apprehensibilis, igitur nec scibilis. Hinc est, quod Commentator super prop. 7 De causis dicit eum nec cadere "sub sensu" aut imaginatione aut "cogitatione aut intelligentia."

2. $\quad$ Cap. $4\left(F\right.$ f. $5^{\text {rb }} ; R$ f. $17^{\mathrm{va}-\mathrm{b}} ; V$ f. $\left.5^{\mathrm{rb}}\right)$-Liber de causis, v(vI), 57, p. 147 , 1. $25^{-27}$

Et ideo dicit divinus Paulus, quod "invisibilia Dei per ea, que facta sunt intellecta, conspiciuntur." Nam "cuiuslibet substantie admiranda propago, quantus sit, suus auctor ostendit," sicut dicitur De articulis fidei prop. 23. Unde "que in rebus" creatis "commendabilia contemplamur per effectum, per causam attribuimus creatori," sicut dicitur in eodem prop. 19. Et ita "per causas, que illuminantur a lumine cause prime," est ipse quoquo modo intelligibilis, sicut habetur De causis prop. 7 .

3. $\quad$ Cap. $12\left(F\right.$ f. $12^{\mathrm{ra}} ; R$ f. $25^{\mathrm{vb}} ; V$ f. $\left.10^{\mathrm{rb}}\right)$-Liber de causis, VI(VII), 64, p. 149, l. 65

Prima igitur ratio ad intenti probationem est, quod quicumque ponit principium unum aut duo, necesse est ipsum ponere ipsum vel ipsa etiam utraque in ultimitate simplicitatis, quoniam, si aliquo modo alterutrum eorum esset compositum, esset ex necessitate partibile et haberet aliquo modo partes; quare neutrum esset principium, cum utrumque multa haberet priora se, videlicet partes suas. Et fundatur hec ratio super sermonem Aristotelis vi Physicorum cap. 1, quod omne compositum dividitur in ea, ex quibus componitur, et item super illud, quod habetur ex prop. De causis 7 , quod simplicis est substantia, que non dividitur.

4. $\quad$ Cap. $13\left(F\right.$ f. $13^{\text {ra }} ; R$ f. $26^{\text {va; }} V$ f. $\left.10^{\text {vb }}\right)$-Liber de causis, I, 1 , p. 134, l. 1 Nec est simile, quod ponit philosophia intelligentias regere mundum sub causa prima, sicut tu postea scies. Nam etsi ipse regant, prima 
tamen causa non absolvitur a regimine, sicut dicit ista positio unum absolvi a regimine alterius, quia "causa primaria est plus influens."

5-6. $\quad$ Cap. 15 ( F f. $15^{\text {rb }} ; R$ f. $28^{\text {va }}, V$ f. $\left.12^{\mathrm{va}}\right)$-Liber de causis, v(vi), 57, p. 147, l. $22 ; 61$, p. $148,1.46-48$

Nam videtur quod sit innominabilis tam secundum sapientes mundi quam sapientes Dei. Primo per hoc, quod dicitur De causis prop. 7, quod "causa prima superior est omni narratione," quoniam "non cadit sub sensu" aut imaginatione, "cogitatione aut intelligentia," et per consequens nec sub "loquela," sicut dicit ibidem Commentator.

7. $\quad$ Cap. $15\left(F\right.$ f. $15^{\text {rb }} R$ f. $28^{\text {va }}, V$ f. $\left.12^{\text {va }}\right)$-Liberde causis, XXI(XXII), 166, p. 181, 1. 68-69; 167, p. 181, 1. 70-71

Ad idem agit, quod dicitur prop. 23, quod "causa prima est super omne nomen, quod nominatur," ad quem "non pertinet diminutio neque complementum," sicut dicit divinus Paulus, quod est "super omne nomen, quod nominatur in hoc seculo aut in futuro." Unde divinus Dionysius De divinis nominibus cap. 7 dicit ipsum "super omne nomen" et intellectum.

8. $\quad$ Cap. $15\left(F\right.$ f. $15^{\text {rb-va }} R$ f. $28^{\mathrm{vb}} ; V$ f. $\left.12^{\mathrm{va}}\right)$-Liber de causis, v(VI), 57, p. 147, 1. $22 ; 57$, p. $147,1.24-27$

Et hoc intelligi potest de nominibus, que non quia, sed quid. Sic dicunt igitur, etsi ipse in se secundum suam substantiam absolutam sit innominabilis, tamen secundum eius bonitatem ex effectu est nominabilis. Propter quod, cum prop. De causis 7 dicitur: "Superior omni narratione," subiungit qualiter et qualiter non. Nam "superior est omni narratione" "propter narrationem esse ipsius," quod est "super omnem causam." Narrabilis tamen est. Et ideo subdit: "et non narratur nisi propter causas, que illuminantur a lumine cause prime."

9-10. Cap. $16\left(F \mathrm{f} .18^{\mathrm{vb}} ; R\right.$ f. $31^{\mathrm{vb}} ; V$ f. $\left.15^{\mathrm{ra}}\right)$-Liber de causis, XXI(XXII $), 166$, p. 181 , l. 68-69; v(vi, 57, p. $147,1.22$

Deus est "quiddam invisibile, ex quo omnia, summum, eternum, incommutabile et nulli effabile nisi tantum sibi, bonum." Et hec similiter tangit causam efficientem et est Augustini Ad Mandarenses Epist. 79. Igitur de invisibilitate Dei dictum est. Quod autem “ex ipso omnia," iam hoc dixit Trismegistus Ad Asclepium, quod ex uno omnia et propter hoc dictus est ipse "omnia." Quod "nulli sit effabile" nisi sibi, indicat illa propositio 16 De articulis fidei: "Deus est immensus, incomprehensibilis, innominabilis, ineffabilis," sicut dicitur De causis prop. 23: "Prima causa est super omne nomen, quo nominatur" et ipse est "superior omni narratione," ut $\langle$ dicitur $\rangle$ prop. $7[\ldots]$. 
11. $\quad$ Cap. $16\left(F\right.$ f. $21^{\mathrm{vb}} ; R$ f. $34^{\mathrm{vb}} ; V$ f. $\left.17^{\mathrm{va}}\right)$-Liber de causis, XVII(XVIII $), 145$, p. $173,1.45^{-47}$

Deus est, a quo exire est mori, in quem redire est reviviscere, in quo habitare est vivere. Hec est similiter Augustini Soliloquiorum I et patet ex dictis. Si enim ipse est vita, a vita exire mori est, et per contrarium ad ipsum redire est reviviscere, hoc est motum vite recipere. Nam "vita est processio procedens ab ente quieto et sempiterno, motus quidem primus," sicut dicitur super De causis prop. 17.

12. $\quad$ Cap. $17\left(F\right.$ f. $22^{\text {va }} ; R$ f. $35^{\text {rb }} V$ f. $\left.18^{\text {ra-b}}\right)$-Liber de causis, XIX(XX), 155, p. $177,1.97-98$

Deus est soluta mens quedam et libera, segregata ab omni concretione mortali, omnia sentiens et movens ipsa, que predita nutu vel motu sempiterno. [...] Quod dicit eum "mentem liberam," insinuat eum non admisceri causatis, sicut dicit prop. De causis 21: "Prima causa regit res creatas omnes, preter quod commisceatur cum eis."

13. $\quad$ Cap. $17\left(F\right.$ f. $24^{\text {rb }} R$ f. $3^{6^{\mathrm{vb}} ;} V$ f. $\left.19^{\mathrm{va}}\right)$-Liber de causis, XXI(XXII $), 166-167$, p. $181,1.68-71$

Deus est sempiternus movens omnia immobilis et incorruptibilis, altissimus, cuius nomen est benedictum et exaltatum exaltatione maxima. [...] Quod sit "exaltatum exaltatione maxima", manifestat prop. De causis 21, que dicit, quod "causa prima est super omne nomen, quod nominatur, quoniam ad ipsum non pertinet neque diminutio neque complementum," secundum quod dicit theologus Paulus Ad Eph. 1: Super "omne nomen, quod nominatur non solum in hoc seculo, set in futuro."

14-16. Cap. 17 ( $F$ f. $24^{\text {va }} R$ f. $37^{\text {ra }} V$ f. $19^{\text {va }}$-Liber de causis, I, 1, p. 134, 1. 1-2; 3, p. 134, l. 6-8; 4, p. 134, l. 10-12; 5, p. 135, l.15; 12, p. 136, l. 39-4O; 13, p. 136, l. $42-43 ; 11$, p. $136,1.29-38 ; 14$, p. 136, 1. 48-137, l. $5^{2}$

"Deus est prima causa unus omnium queque sunt, queque videntur esse, princeps et origo". Hec est similiter Macrobii in eodem et patet ex antedictis. Iam enim nominaverunt ipsum philosophi "causam primam," sicut manifestum est per plures propositiones De causis et per rationes primi, quas supra dixi. Omnium autem causa est quoniam, etsi sunt cause secundarie, tamen "causa primaria plus est influens super causatum suum quam causa secunda universalis," sicut dicit prop. De causis 1, prout Commentator dicit ibidem: "Causa universalis prima agit in causatum cause secunde, antequam agat in ipsum causa universalis secunda" et "cum causa secunda agit in causatum," quod ipsam sequitur, "non excusatur sua actio a causa prima, que est super ipsam," "quoniam est causa ei." Et propter hoc dicit una maximarum: 
"Quidquid est causa cause, est causa causati." Amplius sicut manifestat Commentator ibidem "causa prima est plus comprehendens" et "vehementioris adherentie cum re quam" causa secunda. Unde causa secunda potest separari adherente prima, sicut separato vivere potest remanere esse. "Causa etiam prima adiuvat secundam", et "omnem operationem, quam facit secunda, facit et prima," quamvis efficiat eam per modum altiorem et sublimiorem. Et propter hoc omnium causatorum est causa prima causa.

17-18. Cap. 17 ( $F$ f. $24^{\text {va-b }} ; R$ f. $37^{\text {ra-b }} ; V$ f. $\left.19^{\text {vb }}\right)$-Liber de causis, XVII(XVIII), 145 , p. 173, l. $45^{-47} ; 143$, p. 173, l. $38-40$

Deus est, apud quem est vita fixa, sempiterna in secula seculorum, que nec finitur nec deficit. [...] Hec est Aristotelis I Celi et mundi cap. 15. Quod non tantum apud ipsum sit vita, set quod ipse sit vita, ex superioribus patet. Qualiter autem "vita" sit apud ipsum, per hanc propositionem declaratur, quoniam "fixa et sempiterna" et optima: fixa in substantia, sempiterna in specie, optima in operatione. Omnis autem vita, que non est vita prima, est vita fluens et non fixa, quoniam est motus et processus, sicut definitur vita super 17 prop. De causis, videlicet quod "vita est processio procedens ex ente primo quieto, sempiterno et est motus primus." Vita autem prima est per se vita et omnis vite causa et generativa vite et impletiva et divinissima, secundum quod dicit Dionysius De divinis nominibus cap. $6^{\mathrm{r}}$ et sicut dicitur De causis prop. 17: "Res vive omnes sunt mote per essentiam suam propter vitam primam." Et ideo necesse est, quod ipsa sit vita fixa, nihilominus et sempiterna, quia sempiternum dicitur, quod semper se habet ad esse, et hoc dicitur necessarium, sicut dicit Aristoteles II De generatione cap. 13a.

19-23. Cap. 22 ( $F$ f. $28^{\text {rb }} ; R$ f. $40^{\text {rb }} ; V$ f. $22^{\text {va }}$-Liber de causis, XII(XIII), 109, p. 162, l. 91; 110, p. 162, l. 92-163, l. 94; XIV(Xv), 124, p. 167, l. 50-51; 125, p. 167 , l. 52-55; VIII(IX), 79, p. 154, l. 47-48

Tertia propositionum est, quod principium primum est sciens et intelligens se ipsum. Cuius declaratio est ex propositione, que scribitur $D e$ causis 12, que talis est: "Omnis intelligentia intelligit essentiam suam." Et causa est, secundum Commentatorem, quia, "cum est intelligentia," est intellectus et intellectum.

Modus autem huiusmodi intellectus declaratur prop. 14, et est, quod "omnis sciens, qui scit essentiam suam, est rediens ad essentiam suam reditione completa." Et cum hec reditio sit "per operationem intellectibilem," sicut dicit ibidem Commentator, tunc "ad essentiam", scilicet redire completa reditione, non est nisi essentiam suam perfecte scire vel intelligere. 
Cum igitur "omnis intelligentie fixio et essentia est per bonitatem puram, que est causa prima" necessario, sicut dicitur prop. 8, necesse immo multo fortius ipsa intelligit essentiam suam. Scit igitur se ipsam. Hanc autem conclusionem nititur ostendere Algazel tract. 2 sent. 1.

24-29. Cap. 23 ( $F$ f. $29^{\text {ra }} ; R$ f. $41^{\text {ra }}, V$ f. $\left.23^{\text {ra-b }}\right)$-Liber de causis, $\operatorname{IX}(\mathrm{x}), 92$, p. 158 , l. 8; XVII(XVIII), 143, p. 173, l. 40-41; VIII(IX), 79, p. 154, l. 47-48; V(VI), 57, p. 147, l. 26-27; XVIII(XIX), 149, p. 174, l. 64-65; XX(XXI), 162, p. 18o, l. $48-49$

Constat autem, quod priori modo non intelligit Deus, quia nec intelligentia. Non enim secundum huiusmodi opinionem intelligit per obiectorum presentationem secundum specierum vel formarum expressionem. Nam "omnis intelligentia plena est formis," sicut dicit prop. De causis 9, sed de hoc dicetur in sermone de intelligentiis.

Secundi vero modi intelligendi vel sciendi duo sunt maneries: quarum una est cum receptione, altera vero sine receptione, sicut si aliquis videret solum intus suscipiendo, alter solum extra mittendo. Et harum prima maneries est intelligentiarum, que intelligunt per receptionem; receptionem quidem a superiori, non ab inferiori, sicut manifestat in libro suo De universo et divinus Dionysius quasi per totum Hierarchie angelice.

Hanc autem receptionem et modum eius manifestat prop. De causis 19, cum dicit: "res omnes intelligibiles habent scientiam propter intelligentiam primam," quia, sicut fixio intelligentie est per causam primam, prout dicit alia prop. 8-scilicet "omnis intelligentiae fixio et essentia est per bonitatem puram, que est causa prima"-, sic et scientia eiusdem est per eandem, prout dicit prop. 9: cause secunde "illuminantur a lumine cause prime." "Recipit" enim intelligentia "ex bonitatibus primis, que procedunt ex causa prima, receptionem multam," sicut dicitur prop. 20.

Causam vero primam, quia "dives est per se" ipsam et "magis dives," sicut dicitur prop. 21, impossibile est intelligere per receptionem, alioquin non esset prima, sicut manifestum est supra in propositionibus de quidditate Dei. Impossibile enim est ipsam aliquid recipere, quia impossibile est aliquem ei aliquid dare, sicut dicit theologia nostra: "Quis dedit ei et retribuetur ei?"

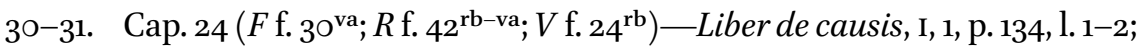
17 , p. $137,1.59-60$

Errorem autem alium, quo dixerunt aliqui scire Deum omnia scientia universali et non particulari, recitat Averroes super XI Prime Philoso- 
phie cap. 24 Et hic error destruitur per tres propositiones. [...] Tertia est, quod "omnis causa primaria plus est influens super causatum suum quam causa secundaria," sicut dicitur De causis prop. 1. Nam quod influit secunda, hoc debetur prime, sicut dicit ibidem Commentator. Ex quibus sequitur, quod prima causa verius est causa omnis causati quam aliqua secundaria, et ideo ipsa est verius principium cognoscendi quam aliqua alia, sicut essendi.

32. $\quad$ Cap. $25\left(F \mathrm{f} .31^{\mathrm{vb}} ; R \mathrm{f} .43^{\mathrm{va}} ; V\right.$ f. $\left.25^{\mathrm{rb}}\right)$-Liber de causis, $\mathrm{XX}(\mathrm{XXI}), 162$, p. $18 \mathrm{o}$, 1. $48-49$

Ita apud primum sunt claves omnium scientiarum, quia ab ipso procedit scientia et cognitio omnium, sicut dicit unus de sapientibus nostris: "Omnis sapientia a domino Deo est." Et item pertractat exemplum: sicut regem, apud quem sunt claves thesaurorum, inconveniens est non appellare divitem, ita eum, apud quem sunt claves omnium scientiarum, inconveniens est non appellare scientem. Si enim dives dicitur, qui habundanter recipit, multo fortius et qui distribuit. Ita est de Deo sciente. Ideo scribitur prop. De causis, quod "primus est dives per se ipsum et est magis dives."

33. $\quad$ Cap. $29\left(F\right.$ f. $34^{\text {va }}, R$ f. $46^{\text {ra }} ; V$ f. $27^{\text {va }}$; ed. Retucci 103, l. 30-104, l. 40$)-$ Liber de causis, $\mathrm{IX}(\mathrm{x}), 92, \mathrm{p} .158,1.8$

Modus autem ponendi ideam intra intellectum creatum est duplex, quorum unus est verus et alter falsus. Verus, ut si intelligamus intelligentias separatas tamquam "artes plures sub una arte divina" uniformi, sicut vult Averroes super XI cap. 6, et movere celos ac per hoc diversas agere dispositiones in hiis, que sub celis sunt, secundum illas species divinas seu ideas, quas inspiciunt in divina mente, que resultant in ipsis inspicientibus, tunc possumus dicere illas species secundas, que resultant ex speciebus primis in mentibus intelligentiarum, aliquo modo ideas, licet secundario. Et huic est consona illa propositio De causis, quod "omnis intelligentia plena est formis." Hinc est, quod intelligentia et anima, cum omnes forme eius actu sint in ipsa, dicitur seculum intellegibile secundum Avicenna lib. $\langle$ VIII $\rangle$ cap. $\langle 7\rangle$.

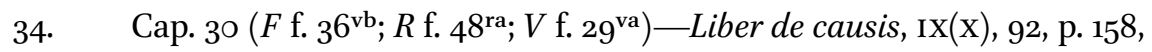
1. 8

Et in hoc solvuntur argumenta Aristotelis III Metaphisice cap. 8, quibus impugnat formas medias [...]. Supra enim concessum est, quod forme abstracte sunt quodammodo per effectum in formis mediis, ut idee in mente conditoris resplendentes in intellectu faciunt ibi species illas, quas dixit Plato medias, secundum sermones, quos dixi tibi, quod "omnis intelligentia plena est formis." 
35-36. Cap. 31 ( $F$ f. $37^{\mathrm{vb}} ; R$ f. $49^{\mathrm{rb}} ; V$ f. $\left.3 \mathrm{O}^{\mathrm{ra}}\right)$-Liber de causis, $\mathrm{Xv}(\mathrm{XVI}), 129, \mathrm{p} .168$, l. $70-71 ; 131-132$, p. 169, l. 79-87

Est igitur secundum ante dicta potentissimus, secundum quod dicit Seneca Epistula 6od: "Maior est"—inquit—“et potentior cunctis." [...] Nam virtus primi est virtus virtutum, per quam est virtus in omnibus intelligentiis, sicut habetur De causis prop. 17: "Omnes virtutes, quibus non est finis, sunt per infinitum primum, quod est virtus virtutum," quoniam virtus intelligentie non est infinita nisi inferius, virtus vero primi infinita est inferius et superius, et ex se ipsa, secundum Commentatorem, et propter hoc est potentior omnibus virtutibus. Unde et merito dicitur "Dominus virtutum" a quodam de sapientibus nostris. Est igitur virtuosissimus et potentissimus.

37. Cap. 36 ( $F$ f. $41^{\mathrm{vb}} ; R$ f. $53^{\mathrm{ra}} ; V$ f. $33^{\mathrm{rb}}$ )—Liber de causis, I, 1, p. 134, l. 1-2 Hec autem ratio perficietur ex dicendis, cum videtur sequi ex hoc, quod hoc necesse est habere rectorem seu providentem, cui magis est ascribendum regimen quam istis, cum "omnis causa primaria plus influat in causatum, quam secundaria," sicut dicitur prop. De causis 1.

Sapientiale, LIBER II

38. $\quad$ Cap. 27 ( $F$ f. $86^{\text {ra }} ; R$ f. $95^{\text {va }}, V$ f. $63^{\text {ra }}$-Liber de causis, $\operatorname{IX}(\mathrm{x}), 92$, p. 158 , 1. 8

Accipe aliam, que est eiusdem libro III cap. 26, quod omnis forma inferior est in superiori, ac per hoc omnes forme inferiores sunt in intelligentia secundum esse nobilius, sicut habetur ab eodem libro III cap. 23, 26, 27 et 38, et prout dicit prop. De causis, quod "omnis intelligentia plena est formis."

39-40. Cap. 27 ( $F$ f. 86 ${ }^{\text {va }} R$ f. $96^{\text {ra }} ; V$ f. $\left.63^{\text {va }}\right)$ Liber de causis, I, 1, p. 134, l. 1-2; 12 , p. 136, l. 41

Si quis autem querat, an ipse primus debeat dici dator forme, intelligat hoc ex prop. De causis 1, que est quod "omnis causa primaria plus est influens super causatum suum quam causa secunda;" et ideo "vehementius est causa rei quam propinqua," sicut dicit ibidem Commentator. Et iam patuit hoc ex sermonibus Avencebrolis. Et propter hoc ipse dicetur verissime dator forme. Unde sapientes Christianorum nominaverunt eum formatorem materie, sicut Augustinus Super Genesim VIII cap. 11; immo forma omnium, sicut idem De religione, propter hoc, quod omnes numeri formarum formantur a prima forma intellegibili, secundum quod dicit idem De civitate Dei libro x cap. 17. 
41-44. Cap. 31 ( $F$ f. $90^{\mathrm{rb}} ; R$ f. $99^{\mathrm{vb}}-100^{\mathrm{ra}} ; V$ f. $\left.67^{\mathrm{rb}}\right)$-Liber de causis, IV, 37, p. 142, l. 37-38; 42, p. 142, l. 51-53; 38, p.142,l. 39-41; 39, p. 142, l.42-43; 4O, p.142, l. $45-46 ; 41$, p. 142, l. $47-48$

Primum autem compositum non est aliud quam existentia prime forme in materia prima. Quapropter primum compositum esse est secundum prop. De causis 4, quod "prima rerum creatarum est esse et non est ante ipsum creatum aliud."

Quod autem oportet hic intelligere nomine esse compositum illud, manifestum est per ante dictum, quia nec materia per se nec forma per se est esse, aut habet esse.

Hoc similiter patet per Commentatorem in eodem loco, qui dicit, quod hoc esse, quamvis sit simplex a Deo, quod non sit "creatum simplicius eo"-creatum dico, quod sit actu ens-, "tamen compositum est ex finito et infinito" et ex materia et forma. Hinc etiam est manifestum, quod oportet extendere hic nomen creationis ad nomen compositionis.

Quod autem hoc esse sit primum illud, de quo dixi, manifestat idem Commentator per hoc, quod dicit, quod est "supra sensum, supra animam, supra intelligentiam et non est esse post hanc causam primam neque prius creatum ipso." Ecce etiam quod dixit esse et esse compositum, nunc dicit causam. Quod autem ipsum sit supremum, dicit, cum adiungit, quod est "superius rebus creatis, omnibus vehementius," et hoc tantum est "propter suam propinquitatem ad causam primam." Istud etiam, quamvis sit unum, propter hoc, quod est propinquum "uni vero, in quo non est multitudo aliquo modorum," tamen multiplicatur et fit multa, quia ipsum est compositum, secundum quod dicitur in eodem loco.

45. $\quad$ Cap. 33 ( $F$ f. $92^{\text {rb }} ; R$ f. $102^{\text {ra }} ; V$ f. $\left.96^{\mathrm{va}}\right)$-Liber de causis, IV, 37, p. 142, 1. $37-38$

Amplius, quomodo primum rerum creatarum erit accidens? Iam enim audisti, quod "primum creatarum est esse, et non est ante ipsum creatum aliud," secundum prop. De causis 4.

\section{Sapientiale, LIBER III}

46. $\quad$ Cap. $5\left(F\right.$ f. $143^{\text {va }} ; R$ f. $149^{\text {rb }} ; V$ f. $\left.74^{\text {va }}\right)$-Liber de causis, I, 1, p. 134, l. 1 Amplius, sicut accommodatur ratio necessitatis rebus possibilibus secundum se quantum ad intentionem essentie, similiter quantum ad intentionem cause. Nam cum nomen cause attribuitur causatis, unde et dicuntur cause secundarie, sicut manifestum est ex De causis 
prop. 1 et aliis locis plurimis, et necessitas attribuitur cause respectu causati, secundum quod dicit Avicenna vi Metaphysice cap. 4, propter hoc sicut est causa duplex, prima, que est simpliciter causa, et secundaria, que est per primam, ita necessitas duplex in ratione causandi: una, que attribuitur cause prime respectu omnis causati; alia, que attribuitur cause secundarie respectu proprii causati, quia omnino necessitas attribuitur cause respectu sui causati, secundum quod dicit Avicenna in eodem.

47-49. Cap. 8 ( $F$ f. $146^{\text {rb }} ; R$ f. $15^{2^{\mathrm{ra}}} ; V$ f. $\left.76^{\mathrm{vb}}-77^{\mathrm{ra}}\right)$-Liber de causis, I, 1, p. 134, l. 1-2; 1, p. 134, l. 1-2; 2, p. 134, l. 2-5; 2, p. 134, l. 6-9; 4, p. 134, l. 10-12; 14 , p. 136 , l. $48-137$, l. 49; 16, p. 137, l. $57-58 ; 17$, p. 137 , l. $59-6 \circ ; 14$, p. 137 , l. $5^{1-52 ; 15}$, p. $137,1.55^{-56} ; 7-11$, p. 135, l. 19-136, l. 38

Scias igitur, quod causas divisionis habet plurimas. Quarum una est, quod causarum alia primaria, alia secundaria, alia naturalis, alia artificialis, alia secundum naturam, alia supra naturam, alia adiutrix, alia preparatrix, alia exemplaris, alia exemplata, alia essentialis, alia accidentalis, alia propinqua, alia remota, alia propria, alia communis, alia particularis, alia universalis, alia simplex, alia composita, alia in potentia, alia in effectu, secundum quod manifestabo tibi breviter omnes illas differentias. Prima igitur divisio est in causam primariam et secundariam, secundum quod habetur ex prop. De causis 1. Causa autem primaria duplicem habet rationem respectu secundarie: unam, quod est causati secundarie cause operativa; secunda, quod non tantum est operativa, sed est magis operativa. Primum est manifestum per prop. 1 De articulis fidei, que est, quod "quicquid est causa cause, est causa causati”, et per communem animi conceptionem, que premittitur, scilicet quod "omnis res habet esse per id, quod causam eius ad esse perducit." Secundum est manifestum per prop. De causis 1, que est, quod "omnis causa primaria plus est influens super causatum suum quam causa secunda universalis," sicut exponitur ibidem ab Alfarabio: primo, quod ad remotionem cause secunde non sequitur remotio cause prime nec virtutis eius. Secundo, quod "causa prima prius agit in causatum secundum cause secunde, antequam agat in ipsum causa secunda, que sequitur eam." Tertio, quod si "causa secunda agit" in causatum suum, non excusatur "a causa prima, que est supra ipsam" et "causa ei," sed "causa prima ipsam secundam adiuvat super operationem suam." Quinto (sic!), quod "non figitur causatum secunde cause nisi per virtutem cause prime," quia causa secundaria operatur ex influentia cause primarie. Sexto, quod causa prima "efficit eam per modum altiorem et sublimorem." Octavo (sic!), quod "causa prima est maioris 
et vehementioris adherentie cum re quam causa propinqua." Et hec omnia sunt manifesta in exemplo, quod ponit in esse vivo homine: "vivum est causa hominis propinqua, esse longinqua," unde est "causa vehementior hominis quam vivum," quia ablato vivo adhuc remanet esse.

5o. $\quad$ Cap. 8 ( $F$ f. $146^{\text {va }} ; R$ f. $15^{22^{\text {rb }} ; ~} V$ f. $\left.77^{\text {rb }}\right)$-Liber de causis, I, 1, p. 134, l. 1-2 Nempe etsi sint medii factori, reducuntur tamen ad factorem primum, qui est factor mediorum et verus operator eorundem. Et ideo ipse est causa ultima omnium efficientium. Valet ad huius rationis confirmationem, quod superius dixi de causa primaria, "quod est plus influens quam causa secunda."

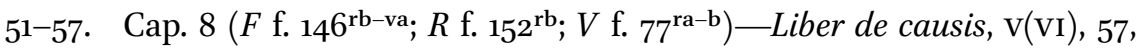
p. 147, l. 22-27; V(VI), 61, p. 148, l. 44-48; V(VI), 58, p. 147, l. 28-31; XIX(XX), 155, p. 177, l. 97-98; 156, p. 177, l. 99-2; 157, p. 177, l. 3-4; XXI(XXII), 166167, p. 181, l. 68-71; XXIII(XXIV), 176, p. 185, l. 20-23

Amplius, sicut habetur ex prop. De causis 6: "Prima causa superior est narratione, et non deficiunt lingue a narratione eius nisi propter narrationem esse ipius, quoniam ipsa est super omnem causam, et non narratur $\langle$ nisi $\rangle$ per secundas causas, que illuminantur lumine cause prime." Et ratio est secundum Alfarabium, quia cum sit superior omnibus, omnia excedit, sensum et intelligentiam et per consequens vocem. Preterea ex commento ibidem habetur, quod "causa prima est, que non cessat illuminare causatum suum, et ipsa non illuminatur a lumine alio, quia ipsa est lumen purum, supra quod non est lumen." Item prop. 20 dicitur, quod "causa prima regit res creatas omnes, preter quod commiscetur cum eis." Et est ratio secundum Alfarabium, "quia regimen non debilitat unitatem eius" nec perturbat essentiam. Unde regens est "stans fixa cum unitate sua prima."

Preterea "causa prima est super omne nomen, quod nominatur, quoniam non pertinet ei diminutio neque complementum." Hoc similiter ex superioribus est manifestum.

Amplius "causa prima existit in omnibus rebus secundum dispositionem unam, sed res omnes non existunt in prima secundum unam dispositionem," sicut dicitur prop. 24.

58. $\quad$ Cap. $11\left(F\right.$ f. $150^{\text {ra }} ; R$ f. $155^{\text {va }}, V$ f. $\left.80^{\text {rb }}\right)$-Liber de causis, I, 1, p. 134, l. 1-2 Et cum hoc ita sit, volo te scire, quod principium non tantum est agens et efficiens aliquorum et aliquorum non, cuius declaratio secundum Rabbi Moysen cap. 67 est quod, cum causatum omne causam habeat, et omnen factum factorem, et omnis factor unus post unum reducitur ad factorem primum tamquam ad agentem et efficientem principalem, 
tunc sequitur necessario, quod ipse est efficiens omnium, et causarum et causatorum, utpote "causa prima plus est influens in causata omnia quam cause secundarie."

59. $\quad$ Cap. $11\left(F\right.$ f. $15^{\mathrm{ra}} ; R$ f. $155^{\mathrm{va}} ; V$ f. $\left.8 \mathrm{o}^{\mathrm{rb}}\right)$-Liber de causis, XXIII(XXIV), 176 , p. $185,1.20-23$

Preterea, sicut dicit Rabbi Moyses cap. 83, "omne, quod exit de potentia ad actum, habet extractorem" sui generis cum eo, idest extracto, alioquin quidlibet extraheret quodlibet, vel ad minus casualis esset extractio, ut esset convenientia inter extrahentem et extractum in forma. Prima autem causa nullius generis est cum alio, cum se habeat secundum unam dispositionem ad omnia causata, secundum quod dicitur De causis. Quare, ut fiat differentia extractorum in singulis generibus, necesse est, ut preter ipsum sint extractores eiusdem generis cum extractis.

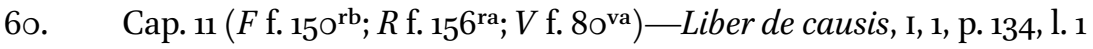
Scito igitur, quod intentio Augustini in sermonibus suis, cum dicit Deum formatorem et formas induci per ipsum in inferioribus, est non excludere ipsum ab operibus secundarium agentium, immo potius attribuere ei principalitatem, cum "causa primaria plus influat," secundum quod dictum est superius. [...] Et hec est via respondendi ad omnes auctoritates, que videntur attribuere formationem rerum immediate creatori.

61. $\quad$ Cap. $12\left(F\right.$ f. $15^{1}{ }^{\text {ra }}, R$ f. $15^{6 \text { va }}, V$ f. $\left.81^{\text {ra }}\right)$-Liber de causis, I, 1, p. 134, 1.1 Quod dicunt homines vilius attribui creatori et nobilius creature, si creatori attribueretur creatio potentie et creature productio actus, hoc verum est. Si excluderetur creator a productione actus per creaturam, $\langle$ falsum est $\rangle$. Nunc autem ipse est "magis influens" in actum "quam secundaria" et immediata.

62-63. Cap. 15 ( $F$ f. $157^{\text {ra }} R$ f. $16 o^{\text {vb }}$; f. $\left.85^{\text {rb }}\right)$-Liber de causis, XVII(XVIII $), 143$, p. $173,1.38 ; 148$, p. $174,1.54-61$

Dico igitur sermone abreviato, quod circumstantia cause denotata in propositione potest dicere aliquid in faciente aut in facto. Si in faciente, sic non dicit nisi causam moventem, sicut supra dictum est. Quod autem hec propositio dicat circumstantiam moventem, manifestum est per propositionem De causis, que est quod "omnia sunt propter ens primum," sicut patet in expositione Alfarabii. Si autem dicat aliquid in facto, sic dicit finem eius ultimum, idest ordinem ad factorem. Et per hoc solvitur ratio eorum, qui posuerunt contrarium, quod etiam universum habet aliquid extra se, propter quod est, videlicet factorem eius, sicut exercitus habet extra se ducem, prout supra dictum est. 
64-66. Cap. 25 ( $F$ f. $170^{\text {ra }} R$ f. $173^{\text {ra }} V$ f. $\left.95^{\mathrm{vb}}\right)$-Liber de causis, $\mathrm{Xx}(\mathrm{XXI}), 162$, p. 18 o, l. 48-49; XIX(XX), 155, p. 177, l. 97-98; 157, p. 177, l. 3-5

Ipso etiam indigent omnia. Nam omne causatum dependet a sua causa et eget ipsa, ut sit et permaneat, sicut superius dictum est in sermone de causa. Et ideo indiget influentia cause sue. Ipse autem est in se sufficientissimus, quia simplicissimus in omnia alia, largissimus, quia summe communicativum. Et ideo quantum ad utramque partem dictum est De causis propositione, quod "primum est dives" quantum ad privationem indigentie in se ipso, et "magis dives" quantum ad influentiam in alios. [...] Item ex tertia proprietate principii, quod est, quod a principiatis separatum, quoniam secundum Aristotelem aliud ab hiis, quorum est principium, manifestum est ipsum esse principium, secundum quod dicit de ipso Avicenna VIII Philosophie prime cap. 1, quod principium omnium est unum, quod est discretum ab omnibus, que sunt. Ipse enim est impermixtus omnibus, secundum quod dicit propositio De causis quod "causa prima regit res creatas omnes, preter quod commisceatur cum eis," quia regens omnia stat in unitate sua propria, secundum quod dicit ibi Commentator. Ipse enim est, qui non communicat alicui eorum, que sunt, nec cui aliquid communicat, sicut dicit Avicenna lib. VIII cap. 5 et lib. IX cap. 1. Quare per hanc viam manifestum est ipsum esse principium.

67-68. Cap. 25 ( $F$ f. $170^{\text {rb }} ; R$ f. $173^{\text {rb }}, V$ f. $\left.99^{\text {ra }}\right)$-Liber de causis, XXIII(XXIV), 176, p. $185,1.20-23$

Amplius, etsi primus adest omnibus, non tamen omnia assunt primo, sicut dicit Augustinus super Principium Iohannis. Et eorum, que assunt, non omnia assunt uniformiter, quoniam "causa prima est in omnibus rebus secundum unam dispositionem, sed res omnes non existunt in prima secundum dispositionem unam," secundum quod exponit ibidem Commentator. Et propter hoc que assunt ipsi in dispositione propinquiori, erunt fortiora et perfectiora, sicut superius dixit Avencebrol.

69. $\quad$ Cap. $27\left(F\right.$ f. $172^{\mathrm{va}} ; R$ f. $175^{\mathrm{vb}} ; V$ f. $\left.97^{\mathrm{vb}}\right)$-Liber de causis, $\mathrm{XXX}(\mathrm{XXI}), 210$, p. 198, 1. 43-44

Preterea ex definitione tertia, que est, quod perfectum est, cui nihil accidit, apposita huic, quod habetur ex propositione De causis, quod "actio primi et substantia est in momento eternitatis," et similiter quod habetur ex Aristotele III Phisicorum cap. 5 et Averroe, quod in eternis non est differentia inter posse vel contingere et id quod est; sequitur necessario, quod nihil ei accidit; quare est perfectissimus. Quippe quidquid est possibile, presens est ei, sicut dicit ultima definitio. 


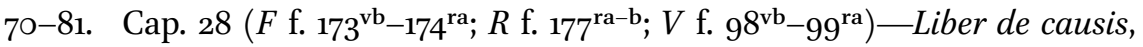
XXVIII(XXIX), 199, p. 192, l. 52-53; 201, p. 193, l. 57-6o; XXVII(XXVIII), 194, p. 191, l. 25-26; VI(VII), 64, p. 149, l. 65; XXVII(XXVIII), 194, p. 191, l. 25-26; XXVIII(XXIX), 199, p. 192, l. 52-53; VI(VII), 64, p. 149, l. 65; XXVII(XXVIII), 195-197, p. 191, l. 27-192, l. 41; XXVII(XXVIII), 197-198, p. 192, l. 42-48; XXIV(XXV), 181, p. 187, l. 61-62; XXVIII(XXIX), 199, p. 192, l. 52-53; $\operatorname{XXIV}(\mathrm{XXV}), 181$, p. 187, l. 61-62; 182, p. 187, l. 66-67; XXIV(XXV), 184, p. 187 , l. 70-188, l. 81; $\operatorname{xxv(xxvI),~187,~p.~188,~l.~83-84;~} \operatorname{xxv(XXVI),~}$ 187, p. 188, l. 83-84; XXVIII(XXIX), 199, p. 192, l. 52-53; XXV(XXVI), 188, p. 189, l. 93-95; 188, p. 189, l. 95-2; 188, p. 188, l. 87-189, l. 9o; 188, p. 189, l. $92-93$

Preterea ex propositione De causis habetur, quod "simplex est substantia, que stat per se ipsam," hoc est "per essentiam suam," quia si non stat per essentiam suam, sed per partes, tunc non est substantia simplex, sed potius compositum ex partibus compositis. Similiter, si habet aliunde fixionem stationis sue quam ex essentia sua, simplex non est. Amplius, si non stat per essentiam suam, ex alio generata est; substantia simplex a nullo est generata; quare non est ipsa substantia, que non stat per essentiam suam, sicut manifestat Expositor in eodem loco. Stare enim per essentiam suam et esse simplex convertuntur, sicut patet ex propositione predicta et immediate precedente, que est, quod "omnis substantia stans per essentiam suam simplex est et non dividitur." [...]

Amplius ex prop. 7 alia adhuc habetur descriptio simplicitatis, que est, quod simplex est "substantia, que non dividitur," que necessario infertur ex duabus supradictis invicem connexis sic: "omnis substantia stans per essentiam suam est substantia, que non dividitur;" sed "simplex est substantia, que stat per essentiam suam;" igitur simplex est "substantia, que non dividitur." Minor huius declarata est. Maior propositio declaratur a Commentatore, videlicet quod substantia stans per essentiam suam est indivisibilis, quia si esset divisibilis, non staret per essentiam suam, sed per partes; aut igitur que per se stant, aut non per se stant. Si priori modo, igitur singule partes stant per essentiam suam sicut totum. Et hoc est impossibile, quia ex eis, quorum unumquodque stat per essentiam suam, non fit unum. Si per partes, que non per se stant, hoc est impossibile, quia substantia, que stat per essentiam suam, stet per partes, que per se non stant. Igitur erit tertio modo, quod stat per essentiam suam, ita tamen quod per partes, quarum una stat per essentiam suam et altera non. Sed hoc est impossibile, quia si sic esset, non esset sufficiens sibi, igitur non esset stans per 
essentiam suam; quod est contra positum. Quare necesse est omnem substantiam stantem per essentiam suam esse simplicem et indivisibilem. Nam si componeretur, tunc haberet partes, quibus staret. Quod non potest esse, sicut iam dictum est.

Item "universitas eius non esset sufficiens per se ipsam, cum indigeat partibus, ex quibus componatur." Ex quo sequitur, quod omnis substantia stans per essentiam suam est substantia simplex, que non dividitur. Et hoc est intentum in hac parte.

Item ex prop. 25 colligitur adhuc alia ratio simplicis, que est, quod simplex est substantia, que non generatur ex re alia, et hoc habetur ex 25, que est, quod "omnis substantia stans per essentiam suam est non generata ex re alia," et predicta, quod "substantia simplex est substantia, que stat per essentiam suam." Igitur substantia simplex est substantia, que non generatur ex re alia.

Maior huius, videlicet quod "substantia, que stat per essentiam, est non generata ex re alia," declaratur per Commentatorem sic: Omne generatum ex re alia est diminutum, et "indigens, ut compleat, eam ex qua generatur"; sed substantia stans per essentiam suam non est diminuta, nec sic indigens; quare non est generata ex re alia. Veritati prime propositionis attestatur ipsa "generatio, que non est nisi via a diminutione ad complementum." Quapropter sequitur ex predicitis, quod "substantia simplex non generatur ex re alia."

Preterea ex prop. $\mathbf{2 6}$ habetur adhuc alia ratio simplicis, et est, quod simplex est "substantia, que non cadit sub corruptione," que similiter sequitur ex duabus, quarum prima est ipsa 26, et est: "Substantia stans per essentiam suam non cadit sub corruptione." Et altera est 29, quam premisi, hec scilicet: "Simplex est substantia stans per essentiam suam;" quare simplex non cadit sub corruptione.

Maior huius declaratur a Commentatore, scilicet quod substantia stans per se ipsam non cadit sub corruptione per huiusmodi propositiones: "omnis causati cadentis sub corruptione non fit corruptio nisi per separationem a sua causa;" sed nullius stantis per essentiam suam est separatio a sua causa; quare nullius talis est corruptio.

Medium patet, quia si possibile esset stantem per essentiam suam separari a sua causa, "possibile esset eam separari a sua essentia," per quam stat; quare possibile esset, ut "stans fixa per essentiam suam sine essentia sua;" quod est inconveniens. Omne enim, quod stat per essentiam suam, sibi est indeficiens, quia semper habet causam sue subsistentie. Quare impossibile est aliquid tale cadere sub corruptione, quia "causa et causatum" in omni tali semper "simul" sunt. 
82. $\quad$ Cap. $28\left(F\right.$ f. $174^{\text {rb }} ; R$ f. $177^{\mathrm{va}} ; V$ f. $\left.96^{\mathrm{rb}}\right)$-Liber de causis, $\mathrm{IX}(\mathrm{x}), 92$, p. $15^{8}$, 1. 8

Preterea sicut ipse (scil. Avencebrol) vult lib. v cap. 16, "substantia, quo fuerit simplicior, eo formarum plurium est receptibilior." Nam "compositio prohibet penetrationem a formis." Igitur quo maior est elongatio a compositione, eo a receptionis formarum impeditione. Amplius, "substantia, quo corpulentior et multiplicior, eo pauciores admittit formas.” Quare quo simplicior, eo plurium erit formarum.

Et propter hoc "omnis intelligentia plena est formis," sicut dicitur De causis propositione. De hoc autem audies alia in sermone De intelligentia, quomodo multe forme possunt esse in una re simplici, et eo plures, quo simplicior; tamen hoc scias, quod nobilitas annexa est simplici.

\section{Sapientiale, LIBER IV}

83. Cap.16 ( F f. $109^{\mathrm{va}}$ in marg.; $\left.R \mathrm{f} .117^{\mathrm{ra}} ; V \mathrm{f} .118^{\mathrm{va}}\right)$-Liber de causis, I, 1, p. 134, 1. 1-2

Preterea tu scis ex supradictis, quod materia non movetur nisi mota. Igitur non numerat nisi numeretur. Igitur antequam numerat materia, est aliquid numerans, quod non potest esse nisi forma. Quamvis enim materia causa per accidens est numerationis, tamen nisi aliquid active numeret, numquam numerabit. Omnis enim causa per accidens reducitur ad per se et omnis passiva ad activam. Omnis etiam effectus debetur per se et primo cause primarie, que plus influit, sicut dicitur De causis prop. 1. Propter hoc cum actus, hoc est forma, dividat, sicut dicit Aristoteles vi Metaphisice, et per consequens primum agens in numeratione materie sit forme, simpliciter numeratio formarum substantialium debetur potius forme quam materie.

84. Cap. $19\left(F\right.$ f. $112^{\text {ra }} ; R$ f. $119^{\text {va }} ; V$ f. $\left.121^{\text {ra }}\right)$-Liber de causis, I, 1, p. 134, 1.1 Amplius, ex tractatu De principio manifestum est, quod omne principiatum habet principium. Unde cum accidens sit principiatum, habebit principium. Quero quod aut accidens aut substantiam. Si substantiam, sed nullum principiatum est principium, nisi per suum principium, nullumque causatum est causa, nisi per suam causam (nam "omnis causa primaria plus influit," sicut dicitur De causis prop. 1); quare si substantia sit principium accidentis, hoc non erit nisi per principia eius, cum ipsa substantia sit principiata; igitur a primo principia substantiarum erunt principia accidentium. Si vero accidens habeat principium accidens, de illo accidente similiter queritur et ibitur in 
infinitum, nisi tandem substantia sit principium accidentium. Et ita revertetur idem quod prius, quod eadem sint principia substantiarum et accidentium.

85. Cap. $22\left(F \mathrm{f} .116^{\mathrm{vb}} ; R \mathrm{f} .122^{\mathrm{vb}}-123^{\mathrm{ra}} ; V \mathrm{f} .124^{\mathrm{ra}-\mathrm{b}}\right)$-Liber de causis, I, 1, p. 134, 1. 1

Preterea illud est verissime unum, quod non dividitur intellectu; omne compositum est divisibilis intellectu, sicut superius manifestavi tibi in sermone De composito; quare primum compositum non est verissime unum, et ideo potest esse principium multorum, maxime cum sit principium per multa, hoc est per principia sua, que sunt multa. Ipsum enim non est principium nisi per sua principia, sicut nec causa secundaria nisi per primariam, secundum prop. De causis 1.

LIBER VI

86. Cap. 15 ( $F$ f. $246^{\text {ra }} ; R$ f. $201^{\text {va-b; }} V$ f. $\left.153^{\text {va }}\right)$-Liber de causis, I, 1, p. 134, 1. 1-2

Et ex hoc est manifestus error ille ingratissimi, qui negat se Deo debere, sed nature, secundum quod dicit Seneca, De beneficiis IV, quia "insita nobis omnium etatum et actuum omniumque artium semina, magister ex occulto Deus producit ingenia." Unde sicut supra dictum est, prima et principalis natura, ex qua hec natura inferior dirigitur et gubernatur, Deus est et divina ratio mundo et mundi partibus inserta. Et propter hoc, quoniam "omnis causa primaria est plus influens," sicut dicitur De causis prop. 1, magis debet causatum suum esse cause prime quam secunde. Et ideo omnis creatura magis debet creatori quam nature.

87. $\quad$ Cap. 20 ( $F$ f. $196^{\text {ra; }} R$ f. $208^{\text {va; }} V$ f. $\left.159^{\text {ra }}\right)$-Liber de causis, $\mathrm{XX}(\mathrm{XXI}), 162$, p. 18 o, $1.48-49$

Scito igitur proprietates primi et descriptiones eius, et primo quod primum est illud, quod est necessarium in esse sequentis, sicut dicit Averroes super v Phisicorum. Item, primum est, quod non indiget secundo, sed econverso, hoc est quo indiget secundum, sicut vult idem super VIII Phisicorum cap. 12. Item, primum est, quod est ante aliud, sicut vult Aristoteles XVI De animalibus cap. 9. Item, primum est, quod est prius secundum esse et definitionem, sicut vult Averroes super viII Phisicorum cap. 12. Item, primum est, quod est causa medii et postremi, sed per medium postremi, sicut vult Aristoteles II Metaphisice, cap. 2. Item, primum est, quod "per se dives et est dives magis," sicut habetur De causis prop. 20. 
88. Cap. $26\left(F\right.$ f. $205^{\mathrm{va}} ; R$ f. $216^{\mathrm{rb}} ; V$ f. $\left.166^{\mathrm{rb}}\right)$-Liber de causis, $\mathrm{Ix}(\mathrm{x}), 92$, p. $15^{8}$, 1. 8

Dico igitur tibi secundum sententiam Augustini et Platonis, quod triplex est esse rei, videlicet in mente divina, in intellectuali natura, in propria existentia; et quod esse eius in natura intellectiva, anima videlicet et intelligentia, medium est inter esse primum et tertium; et quod omnes forme, que exprimuntur in materia, prius naturaliter sunt concreate in intelligentia sive anima, quoniam natura pares sint, sicut dicit Augustinus De libero arbitrio lib. II. Et hoc est consonum propositioni De causis, que dicit quod "omnis intelligentia plena est formis." Hoc esse verum manifestat sermo Augustini [...].

\section{Sapientiale, LIBER VII}

89-93. Cap. 10 ( $F$ f. $224^{\text {rb-va }} R$ f. $249^{\mathrm{va}} ; V$ f. $\left.180^{\mathrm{rb}}\right)$-Liber de causis, XVI(XVII), 138, p. 171, l. 15-16; 139-142, p. 171, l. 17-173, l. 37; VI(VII), 64, p. 149, 1. 65; XX(XXI), 162, p. 18o, l. 48-49; 163-165, p. 18o, l. 5o-181, l. 67

Per naturam ordinis et reductionis creaturarum ad primum est possibile declarare id idem. Nam quidquid est a primo, provenit ab eo secundum ordinem, secundum quod dicit Algazel II Prime philosophie cap. 12. Et ideo reducuntur ad ipsum secundum ordinem, sicut vult Avicenna x cap. 1, quoniam eadem est via reductionis, que est processionis. Reductio autem ad primum est secundum appropinquationem maiorem et minorem, et hec secundum simplicitatem maiorem et minorem, secundum quod habetur De causis prop. 17 et Expositore super eandem, quod omnis virtus, quo primo propinquior, eo simplicior et infinitior et in operatione mirabilior, et per hoc nobilior, quia nobilius in omni genere est simplicius, secundum quod habetur ab Averroe super XI cap. 24. Ex quibus omnibus sequitur, quod creatura primo in ordine naturarum vicinissima est simplicissima; sed talis non potest esse nisi intelligentia, quia vere simplex est, quod nec est compositum neque delatum super rem aliam, prout habetur ex prop. De causis 7, 27 et Commentatore.

94-95. Cap. 11 ( $F$ f. $225^{\mathrm{vb}} ; R$ f. $25^{\mathrm{O}^{\mathrm{vb}}} ; V$ f. $\left.181^{\mathrm{va}}\right)$-Liber de causis, $\mathrm{XXX}(\mathrm{XXI}), 210$, p. 198, 1. 43-47

Preterea per necessitatem mensure, que exigitur inter temporale et eternum, arguitur idem sic: res, que cadit secundum omnes sui dispositiones in tempore et secundum substantiam et secundum actionem, seiuncta est a re, que cadit sub eternitate secundum omnes sui dispositiones et in substantia et in actione. Coniunctio autem non est 
nisi in rebus similibus. Propter hoc necessaria est res aliqua media, cuius substantia cadit in eternitate, idest supra tempus, et actio in tempore, quoniam, sicut inter tempus et eternum est sempiternum medium ita, quod mensuratur sempiterno, erit medium inter id, quod mensuratur eterno, et id, quod mensuratur tempore, quoniam tempus est infra sempiternum et eternum est supra sempiternum. Et hec ratio est Avencebrolis lib. III cap. 2, et habetur ex prop. De causis 31 et Alfarabio super eandem, videlicet quod "inter rem, cuius substantia et actio sunt in momento eternitatis, et inter rem, cuius substantia et actio sunt in momento temporis, est medium. Et est illud, cuius substantia est in momento eternitatis et actio in momento temporis." Non est autem dubium, quin natura corporea secundum quod talis utroque modo sit in tempore. Quare inter naturam corpoream et factorem primum, cuius mensura est eternitas, est aliqua substantia media.

96-97. Cap. 11 ( $F$ f. $227^{\mathrm{rb}} ; R$ f. $25^{2^{\mathrm{ra}-\mathrm{b}} ;} V$ f. $\left.182^{\mathrm{vb}}\right)$-Liber de causis, $\operatorname{XxIX}(\mathrm{XXX})$, 204 sqq., p. 194, 1. 72 sqq.; 204, p. 194, 1. 73-8o

Hec autem substantia intellectiva dirigens naturam in suis operationibus intelligentia 〈est〉 secundum Aristotelem, prout vult Averroes super XI cap. 6. Unde non est mirum, sicut dicit, quod quamvis natura non intelligat de huiusmodi que facit, tamen facit illa aliquam inducendo intentionem et hoc demonstrat, inquit, quod aliquid rememorat ipsam de causis nobilioribus. Verum, ut ante demonstratum est, immediatus motor nature non potest esse motor primus universalis, et ideo necessario est intelligentia. Et causa est secundum Averroem in eodem loco, quia etsi ars una principalis divina, qua regitur natura tota propter hoc, quod ipse idem est rector, qui est auctor, tamen, quia plura sunt artificiata et diversa in natura, que fiunt per multa et multiplicia media, ideo necesse est, quod sint plures artes sub illa arte una prima ab ipsa regulate, per quas quidem regulantur motus et operationes in superioribus et per superiora in inferioribus. Plures autem artes, secundum ipsum, plures sunt intelligentie. Secundum Alfarabium super prop. De causis 3 o probatur idem per propositiones, quas ponit ibidem. Et est prima quod "creata sequuntur se adinvicem," alioquin non essent ordinata inter se, quod negat Aristoteles, XI, cap. 25.

Altera propositionum est, quod "substantiam superiorem non sequitur nisi substantia ei similis et non dissimilis," quantum est possibile, ut assimiletur. Et hoc patet ex priori. [...] Quare sequitur, quod continuatio substantiarum ad primum $\langle$ fit $\rangle$ per assimilationem maiorem et minorem, ut temporalium ad eternam per sempiternas et sempiternalium, quarum una est in tempore, per illam, que est supra tempus, 
idest temporis extensionem, que quidem extensio sit mensura primarum actionum illarum substantiarum. Hec autem continuatio intercisa esset, nisi esset intelligentia. Est igitur intelligentia.

98. Cap. $12\left(F\right.$ f. $227^{\text {va }}, R$ f. $25^{2^{\text {rb }} ;} V$ f. $\left.183^{\text {ra }}\right)$ Liber de causis, XXVII(XXVIII), 196, p. 192, l. 37-41

Amplius, principium per se notum est, quod simplicia naturaliter sunt priora quam composita ex illis; et causa est, quia omne compositum dividitur in ea, ex quibus componitur, secundum Aristotelem vi Phisicorum cap. 1, et etiam in illa resolvitur, secundum quod dicit Avencebrol lib. II cap. 16. Si igitur est aliquid compositum ex duabus naturis, necesse est, quod prioritas illarum ad compositum ex ipsis sit prioritas nature et in ordine essendi. Si igitur inveniatur aliquid compositum ex duabus naturis, quarum una est nobilior alia, secundum quod dicit Alfarabius super 28 prop. De causis, quod omne compositum habet unam partem meliorem et alteram viliorem, et item inveniatur vilior pars illius compositi, ita prior in ordine essendi, ut non tantum sit in ipso composito, sed prius in se habet esse preter compositum, tunc necesse est, quod inveniatur pars nobilior prior per se etiam preter compositum, sicut si inveniatur compositio ex auro et argento, quod est electrum, invenitur utrumque seorsum prius composito.

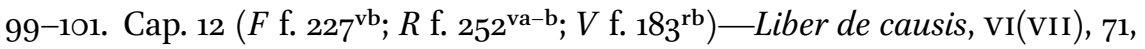
p. 151, l. 1-152, l. 5; VI(VII), 64, p. 149, l. 65; VI(VII), 70, p. 1551, l. 96 Ex quibus omnibus et consimilibus 〈patet〉, quod non esset perfectissimum in operibus altissimi, nisi esset creatura talis incorporea non unita corpori. Imperfectum enim necessario requirit perfectum, et ideo nobiliora et perfectiora priora sunt in esse quam minus nobilia et perfecta. Et ideo si conceditur esse de posterioribus, concedetur de prioribus, secundum sermonem Aristotelis III Metaphisice cap. 11, quod id, quod est nobilius, est prius. Et ad hoc agit, quod vult Aristoteles in eodem libro et capitulo secundum Averroem, videlicet quod id, quod est minoris divisibilitatis, est prius eo, quod est maioris. Non est autem dubium, quin omne corpori unitum naturaliter divisibilius est quam non unitum. Nam tale omne dividitur secundum motum et operationem ad minus et movetur aliquo modo motu corporis, sicut dicit Alfarabius super prop. De causis 7 , et ita divisibile secundum accidens, quamvis non secundum essentiam, sicut distinguit Averroes de indivisibili essentialiter et secundum accidens super III Celi et mundi cap. 3. Unde cum divisibile reducatur ad primum principium, quod est indivisibile omni genere divisionis, per indivisibile et minus indivisibile per magis indivisibile et "intelligentia est substantia, que non dividi- 
tur," sicut dicitur De causis 7, tunc per ipsam intelligentiam corpori non unita est omnium aliorum secundum ordinem essendi ad primum indivisibile tamquam posteriorum per prius reductio. Et iuxta hoc potest fieri argumentum per reductionem entium per rationem unitatis. Nam omne indivisibilius uni primo propinquius, secundum quod dicit Alfarabius super 7 De causis, quod intelligentia, "quia appropinquat uni, fit unum et non dividitur." Igitur quod est divisibilius, non est uni primo propinquius. Propinquius autem est uni substantia, que non dividitur nec alteri unitur quantum ad rationem unitatis; quare talis erit uni primo propinquissima.

102. Cap. 13 ( F f. $229^{\text {ra }}, R$ f. $253^{\text {vb }} V$ f. $184^{\text {ra }}$-Liber de causis, I, 1, p. 134, l. $1-2$ Quod autem dicit Aristoteles non esse substantiam abstractam, que non moveat, non tollit intelligentias nudas corpori non unitas, quoniam et ipse movent sicut amata substantias moventes coniunctas, ad quarum motum moventur celi. Et ideo cum "causa primaria plus est influens quam secundaria," secundum prop. De causis 1, motus etiam corporum celestium magis debentur intelligentiis nudis separatis quam coniunctis. Quod autem dicit Aristoteles substantiam, que non movet, esse in dispositione diminuta, immo potius otiosam, secundum Averroem, falsum est, sicut tu postea scies.

103. Cap. 18 ( $F$ f. $216^{\text {ra }} ; R$ f. $24^{2^{\text {rb }}} ; V$ f. $\left.188^{\text {va }}\right)$-Liber de causis, $\operatorname{IX}(\mathrm{X}), 92$, p. 158 , 1. 8

Et ratio huius est, quod omnia inferiora creata sunt in intellectuali 〈intelligentia〉 angelorum et per consequens animarum, sicut dicit Agustinus Super Genesim libro II cap. 2, addens quod "discretio sive species aquarum, terrarum, nature lignorum, herbarum" et ceterorum omnium prius facta sunt in intellectuali intelligentia quam in propria existentia. Et ideo dicitur De causis propositione, quod "omnis intelligentia plena est formis." Singule autem forme [singule] sunt unitates, ex quibus constituitur numerus, qui non est accidens, sicut supra dictum est in sermone De numero.

104. Cap. $23\left(F\right.$ f. $222^{\text {ra }} ; R$ f. $247^{\text {rb }}, V$ f. $\left.193^{\text {ra }}\right)$-Liber de causis, $\mathrm{XIX}(\mathrm{Xx}), 159$, p. 178, l. $25^{-179}$, l. 31

Item omne agens, cuius actio non est sua substantia, est agens non per se totum, sed aliquid sui; sed omne agens preter primum est agens, cuius actio non est sua substantia; igitur omne agens preter primum est agens non per se totum, sed aliquid sui.

Ratio primi est, quod est agens per se ipsum et non per virtutem et est agens per virtutem et non per se ipsum, sicut dicit Avicenna VI Metaphisice cap. 2. Agens priori modo est agens primus, qui agit per 
suum esse et ideo est agens unita actione, sicut dicitur super 20 Decausis. Omne autem agens preter ipsum est agens per virtutem et non per se ipsum, scilicet totum, et ideo suum agere non est suum esse, sicut sua actio non est sua substantia.

COMPARATIO

F f. 231 $1^{\text {va }} \quad$ Liber de causis, $\mathrm{Xx}(\mathrm{XXI}), 162$, p. 180, 1. 48-49

Preterea primum est dives per se ipsum et est dives maius, sicut habetur De causis prop. 20.

F f. $237^{\text {va }}$ Liber de causis, IV, 37, p. 142, l. 37

Quid autem sit nomen reale compositi primi, ut habet esse preter animam, non video esse, quia uidetur dicere illa propositio $\mathbf{D e}$ causis: "Prima rerum creaturarum est esse," sicut postea patebit in capitulo De ente et esse.

F 238 $8^{\text {va }} \quad$ Liber de causis, IV, 37, p. 142, 1. 37

Nam primum donum divine bonitatis est esse et forte ob hoc dicitur De causis, quod "prima rerum creatarum est esse" et ideo omnium esse est a primo esse.

\section{Bibliography}

\section{Manuscripts}

Evreux, Bibliothèque municipale, 79

Firenze, Biblioteca Medicea Laurenziana, Plut. 83.27

Firenze, Biblioteca nazionale Centrale, Cod. Conv. Soppr. A.VI.437

Madrid, Biblioteca Nacional, 489

Oxford, Balliol College Library, 112

Oxford, Balliol College Library, 232

Oxford, Bodleian Library, Auct. F.5.28

Oxford, Bodleian Library, Digby 67

Oxford, Magdalen College Library, 192

Oxford, Merton College Library, 140

Paris, Bibliothèque nationale de France, Lat. 6506

Paris, Bibliothèque nationale de France, Lat. 16082

Paris, Bibliothèque nationale de France, Lat. 16084

Reims, Bibliothèque municipale, 864

Tours, Bibliothèque municipale, 247

Uppsala, Universitetsbibliotek, Ms. C.595 
Vaticano (Città del), Biblioteca Apostolica Vaticana, Vat. Lat. 1041

Vaticano (Città del), Biblioteca Apostolica Vaticana, Vat. Lat. 2081

Vaticano (Città del), Biblioteca Apostolica Vaticana, Vat. Lat. 4301

Vaticano (Città del), Biblioteca Apostolica Vaticana, Vat. Lat. 6771

Zagreb, Knjižnica Metropolitana, Mr. 97

\section{Primary Sources}

Albert the Great, De causis et processu universitatis a prima causa, II, 1, ed. W. Fauser, Münster, Aschendorff 1993 (Editio Coloniensis 17,2).

Albert the Great, De caelo et mundo, I, 3, 8, ed. P. Hoßfeld, Münster, Aschendorff 1971 (Editio Coloniensis 5,1).

Alexander of Hales, Summa theologica, studio et cura Pp. Collegii S. Bonaventurae, Vol. IV, Firenze, Ad Claras Aquas (Quaracchi) 1948.

Augustine, De civitate Dei, XII, 26, ed. B. Dombart, A. Kalb, Turnhout, Brepols 1955 (Corpus Christianorum. Series Latina, 48).

Augustine, De Genesi ad litteram, viI, 22, ed. J. Zycha, Prag-Wien-Leipzig, Tempsky_Freitag 1894 (Corpus Scriptorum Ecclesiasticorum Latinorum, 28,1).

Augustine, De Trinitate, III, 7, n. 13, ed. W.J. Mountain, F. Glorie, Turnhout, Brepols 1968 (Corpus Christianorum. Series Latina, 50).

Averroes, Super Metaphysicam, IX, comm. 7, in Das neunte Buch des lateinischen grossen Metaphysik-Kommentars von Averroes, ed. B. Bürke, Bern, Francke Verlag 1969.

Berthold of Moosburg, Expositio super Elementationem theologicam Procli, Prop. 14-34, ed. L. Sturlese, M.R. Pagnoni-Sturlese, B. Mojsisch, Hamburg, Meiner Verlag 1986 (Corpus Philosophorum Teutonicorum Medii Aevi, VI,2).

Berthold of Moosburg, Expositio super Elementationem theologicam Procli, Prop. 136159, ed. F. Retucci, Hamburg, Meiner Verlag 2007 (Corpus Philosophorum Teutonicorum Medii Aevi, vi,6).

Berthold of Moosburg, Expositio super Elementationem theologicam Procli, Prop. 160183, ed. U.R. Jeck, I.J. Tautz, Hamburg, Meiner Verlag 2003 (Corpus Philosophorum Teutonicorum Medii Aevi, vI,7).

Bonaventure, Sententiae, II, dist. 18, art. 2, q. 3, studio et cura PP. Collegii a S. Bonaventura, Ad Claras Aquas (Quaracchi), Ex Typographia Collegii S. Bonaventurae 1885, vol. 2.

Bonaventure, In Hexaëmeron collatio, XI, 18, studio et cura PP. Collegii a S. Bonaventura, Ad Claras Aquas (Quaracchi), Ex Typographia Collegii S. Bonaventurae 1891, vol. 5 .

Eustratius, In Ethicam Nicomachean commentarius. Translatio Roberti Grosseteste, I, 4, ed. H.P.F. Mercken, The Greek Commentaries on the Nicomachean Ethics of Aristotle, Leiden, Brill 1973 (Corpus Latinum Commentariorum in Aristotelem Graecorum, VI,1). 
John Duns Scotus, Ordinatio, II, dist. 2, pars 1, q. 4, studio et cura Commissionis Scotisticae, Civitas Vaticana, Typis Polyglottis Vaticanis 1973 (Opera Omnia 7).

Liber de causis - A. Pattin, "Le Liber de causis. Édition établie à l' aide de 90 manuscrits avec introduction et notes," in Tijdschrift voor Filosofie 28 (1966), p. 90-203.

Nicholas of Amiens, Ars fidei catholicae-Ein Beispielwerk axiomatischer Methode, ed. M. Dreyer, Münster, Aschendorff 1993.

Peter Lombard, Sententiae in IV libris distinctae, II, 7, cap. 8-9, vol. 1, Grottaferrata, Collegii S. Bonaventurae Ad Clars Aquas 1971.

Proclus, Elementatio theologica translata a Guillelmo de Morbecca, 56, ed. H. Boese, Leuven, University Press 1987.

William of Auvergne, De Trinitate, 6, ed. B. Switalski, Toronto, Pontifical Institute of Medieval Studies 1976.

\section{Secondary Sources}

Bardenhewer, O. (1882), Die pseudo-aristotelische Schrift Ueber das reine Gute bekannt unter dem Namen 'Liber de causis', Freiburg i.B., Herder.

Beccarisi, A., Porro, P., Imbach, R. (eds) (2008), Per perscrutationem philosophicam. Neue Perspektiven der mittelalterlichen Forschung. L. Sturlese zum 6o. Geburtstag gewidmet, Hamburg, Meiner Verlag.

Beierwaltes, W. (2007), "Primum est dives per se. Das erste ist reich durch sich selbst. Meister Eckhart und der Liber de causis," in Id., Procliana, Spätantikes Denken und seine Spuren, Frankfurt a.M., Klostermann, p. 129-164.

Bos, E.P. (1992), "William of Ockham's Interpretation of the First Proposition of the Liber de causis," in Bos, Meijer (eds) 1992, p. 171-189.

Bos, E.P., Meijer, P.A. (eds) 1992, On Proclus and His Influence in Medieval Philosophy, Leiden / New York / Köln, Brill.

Callus, D.A. (1943), "Introduction of Aristotelian Learning to Oxford," in Proceedings of British Academy 29, p. 229-281.

Calma, D. (2012), "Du néoplatonisme au réalisme et retour. Parcours latins du Liber de causis aux $\mathrm{XIII}^{\mathrm{e}}-\mathrm{XVI}^{\mathrm{e}}$ siècles," in Bulletin de philosophie médiévale 54, p. 217276.

D’Ancona, C. (1991), "Philosophus in libro De Causis. La recezione del Liber de Causis come opera aristotelica nei commenti di Ruggero Bacone, dello ps. Enrico di Gand e dello ps. Adamo di Bocfeld," in Documenti e Studi sulla Tradizione Filosofica Medievale 2, 2, p. 611-651.

D’Ancona, C. (1995), Recherches sur le Liber de causis, Paris, Vrin.

D’Ancona, C. (2014), "The Liber de causis," in S. Gersh (ed.), Interpreting Proclus. From Antiquity to the Renaissance, Cambridge, Cambridge University Press, p. 137-161.

D’Ancona, C., Taylor, R. (2003), "Le Liber de causis", in R. Goulet (ed.), Dictionnaire des Philosophes Antiques, Paris, Editions du CNRS, vol. 1 Suppl., p. 599-647. 
Freddoso, A.J. (1994), “God's General Concurrence with Secondary Causes: Pitfalls and Prospects," in American Catholic Philosophical Quarterly 67, p. 131-156.

Grabmann, M. (1913), "Die Metaphysik des Thomas von York," in J. Geyser (ed.), Studien zur Geschichte der Philosophie. Festgabe zum 6o. Geburtstag Clemens Bäumker, Münster i.W., Aschendorff, p. 181-193.

Hudry, F. (1992), "Le Liber XXIV philosophorum et le Liber de causis dans les manuscrits," in Archives d'Histoire doctrinale et litéraire du Moyen Age 67, p. 63-88.

Iglesias, E. (1946), De Deo in operatione naturae vel volutantis operante, México, Buena Prensa.

Libera, A. de (1981), "Théorie des universaux et réalisme logique chez Albert le Grand," in Revue des sciences philosophiques et théologiques 65, p. 55-74.

Libera, A. de (1992), "Albert le Grand et le Platonisme. De la doctrines des Idées à la théorie des trois états de l' Universel," in Bos, Meijer (eds) 1992, p. 89-119.

Libera, A. de (1997), "Structure du corpus scolaire de la métaphysique dans la première moitié du XIII ${ }^{\mathrm{e}}$ siècle," in C. Lafleur (ed.), L'enseignment de la philosophie aus XIII siècle. Auteur du Guide de l'etudiant du ms. Ripoll 1og, Turnhout, Brepols, p. 61-88.

Libera, A. de (2005), Métaphysique et noétique. Albert le Grand, Vrin, Paris, p. 223244.

Longpré, E. (1926), "Fr. Thomas d'York, O.F.M. La première somme métaphysique du XIII ${ }^{\mathrm{e}}$ siècle," in Archivum franciscanum historicum 19, p. 875-930.

Meliadò, M. (2013), "Theologie und Noetik der Erstursache: der Liber de causis als Quelle Meister Eckharts," in Documenti e Studi sulla Tradizione Filosofica Medievale 24, p. 501-553.

Perler, D., Rudolph, U. (2000), Occasionalismus. Theorien der Kausalität im arabischen und im europäischen Denken, Göttingen, Vandenhoeck und Ruprecht.

Punzi, A. (2016), "Thomas of York's Comparatio sensibilium," in Recherches de Théologie et Philosophie médiévales 83,2, p. 313-352.

Retucci, F. (2008), "Her ûf sprichet ein heidenischer meister in dem buoche, daz dâ heizet daz lieht der liehte: Eckhart, il Liber de causis e Proclo," in L. Sturlese (ed.), Studi sulle fonti di Meister Eckhart, vol. 1, Freiburg, Academic Press Fribourg, p. 135-166.

Retucci, F. (2008b), "Tommaso di York, Eustrazio e la dottrina delle idee di Platone," in Beccarisi, Porro, Imbach (eds) 2008, p. 79-110.

Retucci, F. (2010), "The Sapientiale of Thomas of York: The Fortunes and Misfortunes of a Critical Edition," in Bulletin de philosophie médiévale 52, p. 133-16o.

Reilly, J.P. (1953), "Thomas of York on the Efficacy of the Secondary Causes," in Medieval Studies 25, p. 225-233.

Ruh, K. (1996), “Der Liber de causis," in Id., Geschichte der abendländischen Mystik, Vol. 3, München, Beck, p. 19-32.

Saffrey, H.D. $\left(2 \mathrm{OO}^{2}\right)$, "Introduction," in Thomas de Aquino, Super librum de causis expositio, ed. H.D. Saffrey, Paris, Vrin, p. XV-LXXIII. 
Sannino, A. (2004), "La dottrina della causalità nell'universo di Guglielmo di Alvernia: Percorsi di lettura," in Studi filosofici 27, p. 31-68.

Sannino, A. (2008), "Il Liber viginti quattuor philosophorum nella metafisica di Bertoldo di Moosburg," in Beccarisi, Porro, Imbach (eds) 2008, p. 252-272.

Steel, C. (2002), "Neoplatonic Sources in the Commentaries on the Nicomachean Ethics by Eustratius and Michael of Ephesus," in Bulletin de philosophie médiévale 44, p. 5157 .

Steele, R. (1935), "Introduction" in Rogeri Baconi Quaestiones supra Librum de causis, ed. R. Steele, Oxford / London, Clarendon / Milford (Opera hactenus inedita Rogeri Baconi, 12), p. XV-XXIV.

Sturlese, L. (1978), "Il De animatione caeli di Teodorico di Freiberg," in R. Creytens (ed.), Xenia Medii Aevi historiam illustrantia, oblata Thomae Kaeppeli o.P., Roma Edizioni di storia e letteratura, p. 175-247.

Taylor, R.C. (1983), "The Liber de causis: a Preliminary List of Extant Mss.," in Bulletin de philosophie médiévale 25, p. 63-84.

Treserra, F. (1929), "De doctrinis metaphysicis Fratris Thomae de Eboraco," in Analecta sacra Tarraconensia 5, p. 33-102.

Teske, R.J. (1989), "Introduction," in William of Auvergne The Trinity, or the First Principle, Translated from the Latin by R.J. Teske, F.C. Wade, Milwaukee, Marquette University Press. 